\title{
NBSIR 73-116
}

\section{Study of the Local Resistance of Conventional Plywood Subflooring to Concentrated Load}

Felix Y. Yokel

Center for Building Technology

Institute for Applied Technology

National Bureau of Standards

Washington, D. C. 20234

March 26, 1973

Final Report

Prepared for

Office of Research and Technology Office of Housing and Urban Development Washington, D. C. 20410 

NBSIR 73-116

STUDY OF THE LOCAL RESISTANCE OF

CONVENTIONAL PLYWOOD SUBFLOORING TO CONCENTRATED LOAD

Felix Y. Yokel

Center for Building Technology

Institute for Applied Technology

National Bureau of Standards

Washington, D. C. 20234

March 26, 1973

Final Report

This report is a revision of NBS. 10315

Prepared for

Office of Research and Technology

Office of Housing and Urban Development

Washington; D. C. 20410

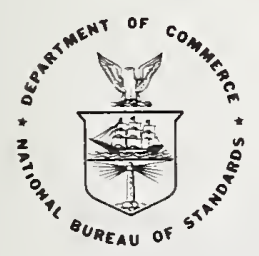

U. S. DEPARTMENT OF COMMERCE, Frederick B. Dent, Secretary

NATIONAL BUREAU OF STANDARDS, Richard W. Roberts, Director 

Study of the Local Resistance of Conventional Plywood Subflooring to Concentrated Load*

by Felix Y. Yokel

Center for Building Technology

National Bureau of Standards

Washington, D. C. 20234

Five conventional plywood floor systems, constructed in accordance with the requirements of the FHA "Ninimum Property Standards" were tested under concentrated loads in order to compare their performance with that stipulated by performance criteria developed on the basis of anticipated occupancy loads.

In 24 out of 26 tests the performance of the floor systems exceeded that required by the criteria. Data on failure loads, load-deflection characteristics and failure modes are presented and discussed.

Key Words: Concentrated-Load Capacity, Evaluation Criteria, Floors, Hardboard, Load Capacity, Operation RREAKTHROUGH, Performance Criteria, Plywood, Plywood Subflooring, Subflooring, Underlayment, Wood-Frame Construction.

* Research Sponsored by the office of Research and Technolory. Department of Housing and Urban Development. 
In view of the present accepted practice in this country for building technology, common US units of measurement have been used throughout this paper. In recognition of the position of the United States as a signatory to the General conference on Weights and Measures, which gave official status to the metric SI system of units in 1960, assistance is given to the reader interested in making use of the coherent system of SI units by giving conversion factors applicable to US Units used in this paper.

Length

1 in $=0.0254$ meter (exactly)

Force

$I$ Ib $(I b f)=4.448$ Newton $(N)$

Pressure

$\operatorname{lpsi}=6895 \mathrm{~N} / \mathrm{m}^{2}$

Temperature

$5 / 9$ (Temperature $\left.{ }^{\circ} \mathrm{F}-32\right)=$ Temperature ${ }^{\circ} \mathrm{C}$ 
TABLE OF CONTENTS

1. Introduction. . . . . . . . . . . . . . . . . 1

1.1 Purpose of Study . . . . . . . . . . . . . . 1

1.2 Background Information . . . . . . . . . . . 1

2. Scope of Testing Program. . . . . . . . . . . . . 6

3. Test Specimens. • . . • . • . • . . • • • . . 7

3.1 Materials. . . . . . . . . . . . . . . . 7

3.2 Description of Specimens . . . . . . . . . . . 8

4. Testing Procedure . . . . . . . . . . . . . . . . . 11

5. Test Results. • . . . . . . . . . . . . . . . 13

6. Interpretation of Test Results. . . . . . . . . . . . 15

6.1 Compliance with the criterion. . . . . . . . . 15

6.2 Failure Modes. . . . . . . . . . . . . . . . 18

6.3 Effect of Test Location on Load Capacity and

6.4 Relative Stiffness of Floor Systems. $\cdot$ •

7. Conclusions . . . . . . . . . . . . . . . . 23

8. Acknowledgement . • . • • • • • • • . • • . . 24

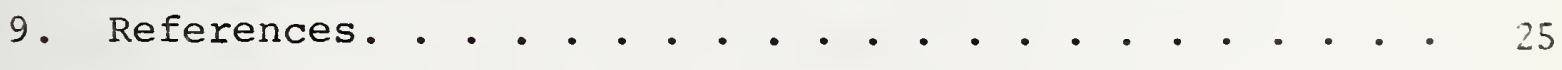



1. Introduction

1.I Purpose of siudy

This study was conducted as part of an effort to develor and improve evaluation criteria for sndustrialized housing.

The criteria were used to guide the development and evaluation of prototype housing for the Department of Housing and Urban Development's Operation BREAKTHROUGH.

The subject of this study are requirements for the resistance of floors to concentrated load. The objective of the study is to determine the level of performance of conventional floor systems and compare their performance with that required in the evaluation criteria for Operation Breakthrough[1] I/, which were based on anticipated occupancy loads.

\subsection{Background Information}

1.2.1 The need for Evaluate the Structural Performance of Floors Under Concentrated Load

Present U.S. building codes and design standards for residential construction provide for floor capacity under distributed load. The only U.S. recommendation related to concen trated loads acting on floors is contained in a nerformance standard by IHFA [2] which is advisory and not enforccahle. The standard recommends deflection limitations under a $250-15$ concentrated load, and an "extented-load capacity" of $4501 \mathrm{~b}$

1/Figures in brackets indicate literature references 
with a residual deflection not to exceed 25 percent of the maximum deflection. The concentrated loads are to be applied over a l-inch diameter area.

The lack of enforceable provisions for concentrated-load capacity is not attributable to a lack of need for such provisions. It is merely brought about by the fact that codes are based on conventional building systems, which by and large tend to perform in a manner accpetable to the user under conditions of normal use. On the other hand it is envisioned that some innovative systems may comply with code provisions for distributed loads, but exhibit unsatisfactory performance under other types of occupancy load. It is therefore necessary to evaluate these innovative systems under various types of loading generated by occupancy, including critical concentrated loaảs.

1.2.2 Occupancy-Generated Concentrated Loads Acting on Floors Concentrated loads on floors may be caused by heavy furniture or by human activity. Two critical conditions are identified:

1. A concentrated load of critical magnitude that may cause damage to the entire floor, or more likely to a section of the floor, by exerting excessive bending moments and/or excessive shear.

2. A load that is concentrated over a very small area, thereby causing failure by excessive compressive stress and/or excessive punching shear. 
Typical heavy concentrated loads have been studied by Boyd [3] and are summarized below:

1. A person carrying a heavy 1oad...............350-450 1b

2. A crowded sofa (per front caster)...........300-350 1b

3. An upright piano (1 caster).................... Ib

4. A grand piano (1 caster) ......................... b

5. Transportation of an upright piano (per whee1).250-350 1b

6. Transportation of a grand piano (per whee1) ...350-450 1b Boyd concluded that since the use of grand pianos is relatively rare, the following design-loads should be used:

(a) 400 Ib for several seconds

(b) $350 \mathrm{Ib}$ for $1 / 2$ hour

(c) $2001 \mathrm{~b}$ indefinitely.

In extreme cases some casters may spread these loads over an area as small as $0.5 \mathrm{in}^{2}$.

Critical loading caused by load concentration over a small bearing area is also caused by stiletto heels. Even though these heels may no longer be fashionable, their future use cannot be ruled out. A study of typical stiletto-heel pressures [4] indicates a range of compressive stresses from 550 psi to 1390 psi, and one extreme value of 2,260 psi. Values of punching shear computed from these data range from $80 \mathrm{lb} /$ in to $117 \mathrm{lb} / \mathrm{in}$. The case that produced the 2260-psi compressive stress produced a punching shear of $156 \mathrm{lb} / \mathrm{in}$. 
1.2.3 Discussion of Evaluation Criteria for Concentrated Load on Floors

The following criterion has been adopted as a guide for Operation BREAKTHROUGH [1]:

"The structural floor should resist a 400-1b lcad, applied on a circular area of 5/8-in diameter and sustained for one hour, without causing a resiclual indentation of the structural surface in excess of $1 / 16 \mathrm{in}$, measured 1 hour after removal of the load, and a 280 lb long-term sustained load, applied on a circular area of $5 / 8$-in diamerer.

If the wearing surface is of non-durable material, or if there is a possibility that this surface may be removed during the useful life of the structure, the floor should satisfy (this) criterion with the wearing surface removed."

This criterion is intended to test the structural floor and not the wearing surface. However, permanent-type wearing surfaces which are left in place throughout the service-life of the building may have a beneficial effect on the load capacity of structural floors which could be relied upon.

The criterion requires reasonable deflection recovery under a 400-1b concentrated load sustained for one hour, and a 280-1b long-term sustained-load capacity. The term "sustainedload" capacity is not defined in the criterion. In this investigation it is assumed that the intent of the criterion is that a 280-1b load applied over a 5/8-in diameter area continuously during the service life of the structure should not cause serious distress.

The 400-1b requirement would be in many cases associated with the capacity to support a higher short-term load; however, the relationship between the short-term capacity, the ono-hour capacity, and the long-term capacity would depend on the 
material of the structural floor. As an example, this relationship is considered for the case of wood.

The following approximate capacities can be calculated using the information in Reference [5] and assuming that capacities are interpreted in terms of maximum residual deflection and that the residual deflections are related to flexural strength:

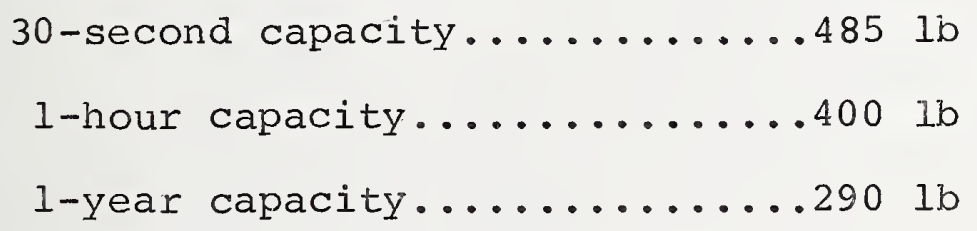

on the other hand, for another material, instantaneous and long-term capacities may differ very little from the one-hour capacity •

The compressive stress caused by the 400-1b load required in the criterion is 1300 psi and the punching shear is 203 1b/in. If we compare the concentrated load, the compressive stress and the punching shear with the data in section 1.2.2, it is evident that the criterion represents reasonable minimum requirements with no substantial margin with respect to extreme occupancy loads. However, it should be noted that some of the extreme loads, caused by the moving of heavy furniture, could be modified or avoided by simple precautions.

The loading requirements in the criterion differ from existing techniques, such as the ASTM E72 test [6] and the ASTM D 2394 test [7]. Both of these tests methods use a 1-in 
diameter disc to transmit the load, while the criterion requires a 5/8-in diameter loading area.

The E72 test is intended to measure the structural capacity of the system, and the D2394 tests measure the strength of the finished flooring. These tests, with proper choice of load levels, could adequately evaluate most floor systems. A problem, however, arises with floor systems that consist of a thin structural skin supported by stiffening elements. In this case the system may perform satisfactorily under the D2394 test, while under different support conditions the structural skin may fail by punching shear. On the other hand, in order to generate adequate stress under a l-in diameter disc, the concentrated load would have to be increased to over 1000 Ib, and in order to generate adequate punching shear the load would have to be increased to at least 500 Ib. These heavier concentrated loads would be higher than the extreme concentrated loads that actually act on the floor in service.

2. Scope of Testing Program

Seven different types of plywood subflooringl/ were tested, representing typical minimum construction standards presently used. Most of the subfloring specimens tested were supported

2/The structural material or surface which supports floor loads and the finish flooring. If the subfloor material is sufficiently dense, smooth, stiff, dimensionally stable and pos-sesses adequate bonding properties, finish flooring may be applied directly without the use of underlayment. 
by wood joists of $2 \times 4$-in nominal size, spaced 16 in on center. In a small number of specimens joist spacings of $24 \mathrm{in,} 20 \mathrm{in,} 10 \mathrm{in}$ and 6 in were used in order to investigate failure modes. The small 4 -in joist depth was selected, since in all cases the joists were fully supported, and joist deflection and hence, joist size, was not a variable considered in this investigation. Test loads were concentrated loads which were increased until failure occurred. For part of the specimens loads were applied in several cycles of unloading and reloading. Deflections were measured near the point of load application. The test loads were applied over circular areas of 1 in, $5 / 8$ in, and in a limited number of tests, $1 / 2$ in diameter. Table 2.1 shows the test variables and the scope of the testing program.

3. Test Specimens

\subsection{Materials}

All materials were purchased from local suppliers and were typical of those presently used in building construction. Plywoods met the requirements of Product Standard PSI-66 [8] for softwood plywood. Dimensions and physical properties of the different plywoods used are shown in tahle 3.1 . 
Hardboard underlayment $3 /$ complied with Federal Standard LLLB-810a, Type VI [9]. Dimensions and physical properties of the hardboard used are shown in tabje 3.2 .

Wood joists are Construction Grade $4 /$ Douglas Fir. Moisture content was 9.7 percent $5 /$ and specific gravity was $0.41 .6 /$

3.2 Description of Specimens

All the standard specimens were constructed in accordance with the provisions in "FHA Minimum Property Standards" [15], Sections 817.3 and 817.4

Standard Specimens were constructed in small widths compared to the size of plywood sheets actually used in construction. This provided simulated conditions representing the least strength and stiffness that the floors may be expected to develop in service.

3.2.1 Standard Specimens without Underlayment Figure 3.1 shows a typical specimen. The $2 \times 4$ joists were 16 in long and were spaced 16 in on center. Plywood

3/ Hardboard is a dense panelboard manufactured of wood fibers with the natural lignin in the wood reactivated to serve as a binder for the wood fibers. Underlayment is a material installed over the subfloor to provide a suitable base for the finish flooring when the subfloor does not possess the necessary properties for direct application of the flooring.

4/In accordance with WCIIB Rules No. 14 [10]

5/ Determined in accordance with ASTM D2016 [13]

6/ Determined in accordance with ASTM D2395 [14] 
sheets, nominally $1 / 2$ in thick, 14 in wide, and 48 in long, were nailed to the top and bottom faces of the joists. The plywood sheets were oriented with the grain of the outer plies perpendicular to the axis of the joists. The joists were 2 in longer than the width of the plywood sheet to give the specimens stability under concentrated load, which was applied at the long edge of the plywood. The plywood sheets were nailed to the joists with $8 \mathrm{~d}$ common nails. Three nails, spaced 6 in on center, were used for the two outside joists. The inside joists were nailed with two nails, spaced 10 in on center.

Standard specimens, as described in this section, were made for three different floor systems:

System A, using plywood a?/

System B, using plywood b

System C, using plywood C

3.2.2 Standard Specimens with Underlayment

Figure 3.2 shows a typical standard specimen with underlayment. The two 48-in long $2 \times 4$ joists were spaced 16 -in on center. Four 12-in long by 16-in wide sections of nominally 1/2-in thick plywood were nailed to the top and bottom faces of the joists. Each 12 x 16-in plywood section was nailed on each side by three $8 d$ common nails, spaced 5 in on center. This spacing was less than the 6-in spacing required in "FHA Minimum Property Standards." The reduced nail spacing was chosen in

T/For description of plywoods refer to section $3 . I$ and talu $1 \mathrm{c}$. 
order to compensate for the fact that this specimen was only 16 inches wide, while in an actual building an $8 \mathrm{ft}$ sheet would be used, providing continuity at least at one of the two joist supports. The 1/2-in plywood sheets were oriented with the grain of the outer ply perpendicular to the axes of the joists. A continuous sheet of underlayment, 16 in wide by 48 in long, was nailed to the outer face of the $1 / 2$ in plywood sheets. This underlayment consisted of either 7/32-in thick hardboard or 1/4-in thick plywood. The underlayment was nailed to the 1/2-in plywood sheets by 4 d annular-thread nails spaced 6 -in on center.

Standard specimens with underlayment were made for four different floor systems:

System D, using plywood d with 7/32-in hardboard underlayment;

System E, using plywood $\mathrm{c}$ with 1/4-in plywood underlayment;

System $F$, using plywood $c$ with 7/32-in hardboard underlayment;

System G, using plywood c with 1/4-in plywood underlayment.

3.2.3 Specimens with Other Than 16 in Joist Spacing

Several Specimens were made with other than 16 in joist spacing. These specimens were all without underlayment and were similar to the specimens described in Section 3.2.1 with the exception of the joist spacing. 
4. Testing Procedure

The specimens were fabricated and stored in the laboratory at approximately $73^{\circ} \mathrm{F}$ and 50 percent relative humidity. 'I'he tests were performed in the same laboratory.

The load was transmitted from the head of a 60,000-1b capacity testing machine. The test setup is shown in figuro 4.1. The specimen rested on the platten of the testing machine. Load was applied to the specimens through the end of a 6.5 -in long steel rod. The end of this rod was sharp edged and machined to the required diameter. The steel rod was connected to a load cell which was inserted between the upper end of the rod and the head of the testing machine.

Deflection $8 /$ was measured by a displacement transducer (IVDT). The transducer was connected to a base, made of a $2 \times 4$ wood member, 18 in long, that rested on three adjustable bolts. These bolts were so spaced that the base could be supported on the centerline of two joists on 16 in centers. Deflections were measured to the face of a bracket which was

8/The term "indentation" used in the criterion was interpreted as a deflection of localized nature which was measured relative to two points on the surface of the floor, spaced 16 in apart and which in some cases included a well defined indentation of the floor surface, as well as a localized deflection between two adjacent supporting joists. In the case of the standard specimens, the measured deflections at the critical locations were referenced to two points at the floor surface located above the centerlines of two adjacent supporting joists. 
connected to the upper end of the load cell, thus measuring the downward movement of the loading device relative to points, spaced $\mathbf{1 6}$ in apart and located at the surface of the specimen. The distance between the centerline of the displacement transducer and the centerline of the loading rod was 4 in.

Deflections thus measured also included shortening of the loading rod and the load cell. To determine the magnitude of this effect the shortening of the rod and the load cell was measured for loads up to $1000 \mathrm{lb}$. It was determined that the effect of this shortening on test results was of second order magnitude and corrections for this effect were therefore unnecessary.

Data were recorded electronically by transmitting the output from the displacement transducer and the load cell to an $X-Y$ recorder. The $X-Y$ recorder plotted loads on the $Y$ axis to a scale of 100 lb per 1 in, and deflections on the $\mathrm{X}$ axis to a scale of 0.1 in per 1 in. This produced a graphical record of the data which had adequate resolution.

The load was applied at a rate of $1 / 2$ 1b/sec. Most specimens were loaded continuously to failure, but several specimens were subjected to cycles of unloading and reloading. After each load increment of 100 lb these specimens were completely unloaded and reloaded to a load 100 lb greater than tire previous load or to failure, whichever came first. This procedure left a record of instantaneous deflection recovery for each specimen. On two specimens, a 400-1b load was maintaincd 
for one hour and the specimens were then unloaded and deflection recovery was measured after one hour. In some tests failure occured at loads higher than $1000 \mathrm{lb}$. In these cases the load cell which had a 1000-1b capacity was removed prior to the completion of the test and loads were measured by the testing machine. For these tests, only failure loads as defined in Section 5 were recorded since the deflections at failure were not measured.

\section{Test Results}

The test data which consist of a plotted load-deflection curve for each specimen tested are summarized in table 5.1. The first column in the table identifies the floor system, in accordance with the list of floor systems in table 2.1. The diameter of the loaded area is shown in the second column, the joists spacing in the third column, and the location of the test load in the fourth column. Test-load locations are identified as shown in figure 5.1. The other three columns identify failure load, load causing initial structural damage, and deflection at failure load, respectively.

The method by which these values were determined is illustrated in figure 5.2 which shows a typical load-deflection curve. In general, specimens could be loaded to a certain level without any sign of distress. First signs of distress, which were usually associated with some cracking sound, can be identified on the load-deflection curves as a drop in the applied load which is not associated with a change in deflec- 
tion. Such a drop in load is associated with a residual deflection which is roughly proportional to the magnitude of the drop in load. The load level at which this first distress occurred is identified in column 6 of table 5.1 , and is shown in figure 5.2. If loading was subsequently continued, most specimens were able to support additional load increments without an appreciable change in the slope of the load-deflection curve, until an additional drop in load occurred at a higher load level.

The failure load in column 5 of table 5.1 identifies the lowest load level at which a load drop of 30 lb or more occurred. This point does not always represent the highest load that the specimen can support. The definition of failure load is based on the observation that a load drop of $30 \mathrm{lb}$ was associated with irrecoverable deflections approaching $1 / 16 \mathrm{in.}$. It is reasonable to assume that after such a drop in load most specimens would not meet the deflection-recovery requirements in the criterion which specifies a residual deflection of less than l/16 in, and that a clearly identifiable residual deflection would remain on all specimens after removal of the load.

The information presented in Table 5.1 is sumarized in Table 5.2, where the average loads causing failure and initial distress are tabulated for specimens with 16-in joist spacing. other information that can be derived from the test data, together with plots of typical load-deflection curves, is presented in section 6 where test results are interpreted. 
6. Interpretation of Test Results

6.1 Compliance with the Criterion Adopted for Operation BREAKTHROUGH

6.1.1 Concentrated-1oad capacity

Figure 6.1 is a plot showing the range of load capacities and average load capacities for specimens with 16-in joist spacing. The test data are for test locations 1 and 1 i in figure 5.1 since these locations are considered critical. Actually tests at locations 3, 4, and $2 \mathrm{u}$ yielded lower results, however, in accordance with good construction practice, free edges of plywood sheets should be blocked when 1/2-in thick plywood is used or tongue and groove joints should be provided for thicker plywood sheets. Compliance with the criterion at test locations 3,4 and $2 \mathrm{u}$ is therefore not required.

The shaded rectangles in figure 6.1 show the range of the failure loads and the unshaded rectangles show the range of loads that caused initial distress. The solid and hollow circles $9 /$ show the average loads at failure and initial distress respectively. Test results are plotted for loaded areas of $5 / 8$ in, as well as 1 in diameter. The heavy horizontal line shows the load level required by the criterion.

The following conclusions can be derived from figure 6.1:

1.) All specimens tested failed at load levels equal to, or higher than that required by the cricerion.

\footnotetext{
9/In some cases the test results do not crer a significant range, or only one single test was performed. In these cases only the solid and hollow circles are shown.
} 
2.) Except for floor system E, all specimens tested : hownd fist sians of distress at load levels equal to or higher than that required by the criterion. For system E, two out of the three specimens tested showed first signs of distress at load levels higher than that required by the criterion, and the third specimen showed first signs of distress at a load of $390 \mathrm{lb}$.

3.) In all cases, specimens tested by the 1-in diameter disc had significantly greater load capacity than specimens tested with the 5/8-in diameter disc.

The overall conclusion is, that except for one specimen in system E, all specimens satisfied the criterion and most specimens exceeded the capacity required in the criterion by a substantial margin. It should be noted that this conclusion is based on a test setup which uses specimens of 14 in and 12 in width, respectively. This is a simulation representing the least strength that a floor may be expected to develop. In an actual building; where floors are continuous over much larger areas, load capacities may be somewhat higher.

\subsubsection{Deflection Recovery}

Figure 6.2 shows the load-deflection curve for a test in which floor system $C$ was loaded in accordance with the requirement of the criterion. Deflections are plotted along the abscissa, and loads along the ordinate. 
Note that the instantaneous deflection under the $400-1 \mathrm{~b}$ load was approximately 0.178 in. When the load was sustained for an hour, this deflection increased by 0.012 in and when the load was removed, there was an instartaneous deflection recovery to a residual deflection of 0.02 in. One hour after unloading, the remaining residual deflection was 0.01 in. Thus the residual deflection measured for this specimen was substantially smaller than the maximum $1 / 16$-in (0.0625 in) residual deflection stipulated by the criterion.

Figures 6.3 through 6.7 show deflection-recovery characteristics for floor systems $A, B, C, F$, and $G$, respectively. In all cases the residual deflection, measured immediately after removal of the 400-1b load, was substantially less than $1 / 16$ in. This is taken as an indication that all these floor systems have deflection-recovery characteristics which would satisfy the criterion. Fioor systems $D$ and $F$ were not tested uncier cycles of unloading and reloading. The observation that loaddeflection curves for the tested specimens of floor systems D and $E$ tended to be linear below the $400-1 b$ load is taken as an indication that these systems have deflection-recovery characteristics similar to those of systems $A, B, C, F$, and $C$.

\subsubsection{Sustained-Load Capacity}

No long-term tests were conducted to determine the sustained-load capacity of the specimens. Some indication of the magnitude of that capacity can be derived using the data presented in reference [5]. In accordance with these data, a 
1-hour capacity of 400 lb would correspond to a 1-year capacity of $290 \mathrm{lb}$ and to a 30-year capacity of $265 \mathrm{lb}$.

If we define the 30-year capacity as the required sustainedload capacity, a one-hour capacity of 422 lb would satisfy the 280-1b requirement in the criterion. Of the 26 specimens tested at load locations 1,2 and $1 \mathrm{u}, 24$ exceeded this capacity. Thus it can be concluded that the floor systems tested generally satisfy the requirement for sustained-load capacity.

\subsection{Failure Modes}

Figures 6.8 and 6.9 illustrate two typical modes of failure. Figure 6.8 shows a typical failure of a specimen of floor system A loaded over a l-in diameter area and gives the appearance of a flexural tensile crack. Figure 6.9 shows the failure mode of a specimen of floor system B, loaded over a 5/8-in diameter area, which is typical for most specimens under this loading except for specimens that were loaded over the joist support at locations 5 and $3 u$. This mode of failure has the appearance of a combination of a local shear failure (punching shear) in the upper four plies together with a flexural tensile failure in the lowest ply.

When test results are interpreted, some conclusions could be drawn from a theoretical consideration of the effects of the variation of the loaded area, the joist spacing, and the location of the applied load. The following theoretical considerations apply to loads acting at locations 1,2 and $l u:$ 
1.) Flexural stress would vary with joist spacing, however the diameter of the loaded area would have relatively little effect. Flexural failure would probably occur under the loaded area.

2.) Local (punching) shear would vary with the diameter of the loaded area and would not vary with joist spacing. Failure by local shear would occur close to the perimeter of the loaded area.

3.) Vertical compression would vary with the diameter of the loaded area ard would be independent of the location of the loaded area and of joist spacing.

Indentations caused by vertical compression were determined in the testing program by applying concentrated loads over the joists at locations 5 and $3 u$. On this basis it was determined that vertical compression would not be critical for the l-in and the 5/8-in diameter loading discs. The 1/2-in diameter disc was ruled out on the basis of tests performed at location 5 on floor system $\mathrm{C}$ where it caused a residual deflection in excess of 1/16 in under a 400-1b load. Data for these tests are shown in table 5.1.

Some conclusions about the failure mode can be drawn by considering the effect of joist spacing and of the diameter of the loaded area. It has already been noted in section 6.1 .1 that load capacity increased with an increase in the diameter of the loaded area. This effect, and the effect of joist spacing are illustrated in figures 6.10 and 6.11 . 
Figure 6.10 shows the effect of joist spacing on failure loads and load levels at which initial damage occurred in system $A$. Note that there was considerable variation in strength between individual specimens. The average values therefore only represent approximate trends since the number of samples used was small.

For the 1-in diameter test load there was no difference in strength between the 6-in and the 10-in joist spacing. At these spacings failure probably occurred by punching shear. For larger joist spacing the failure load dropped with increased spacing. This drop, together with the characteristics of the typical failures which is shown in figure 6.8 , leads to the conclusion that these specimens probably failed by flexural compression and tension.

For the 5/8-in diameter test load the failure load tends to decrease with increased joist spacing between the 6 -in and the 16-in spacing. For spacings larger than 16 in the failure load increased. This inconsistency may be attributable to the strength variability (this sample was too small to be statistically significant). The dashed curve, which shows loads causing initial damage, shows a consistent decrease of load with increased joist spacing. Since for flexural failure the failure load would be independent of disc-size and for local shear the load would be independent of joist spacing, it is concluded from figure 6.10 that for the 5/8-in loading diameter failure probably was caused by a complex combination of flexural stresses and local shear. 
Figure 6.11 shows the relationship between load capacity and joist spacing for floor system $B$, loaded over a 5/8-in diameter area. In this case capacity only slightly decreased with joist spacing. The dominant failure mode for these specimens was probably local shear. Tests on specimens with other than 16-in joist spacing were only performed for floor systems $A$ and $B$.

6.3 Effect of the Test Location on Load Capacity and Stiffness 6.3.1 Floor Systems Without Underlayment

Floor systems $A, B$ and $C$ were tested at 5 different locations. Locations 1 and 2 were between joists and 6 in from the free edge of the plywood sheet. These locations differed only in the fixity of the plywood sheet at the joist support. At location 1 the edge of the plywood was nailed to one joist support and the plywood was continuous over the other joist support. At location 2 the plywood was continuous over both joist supports. It was reasoned that location 1 should be weaker than location 2 since there was less fixity at the joist that supported the edge of the plywood sheet. However, comparison of the average test results in table 5.2 indicates that the strength at location 2 was similar to that of location 1 in systems $A$ and $B$. Only system $C$ had greater strength at location 2. Locations 3 and 4 were at the edge of the plywood sheet between joists and represented points of least strength. This can be seen from the data in table 5.2. Location 5 was 
over the joist support, and as expected, supported much higher loads.

A comparison of load-deflection characteristics for the various loading points is shown for system A in figure 6.12 . As expected, location 5 is the stiffest. There is little difference in stiffness between locations 2 and 1 , and locations 3 and 4 also have comparable stiffness: This is consistent with the observation that there was no significant difference in strength between locations 1 and 2 , as well as between locations 3 and 4 .

Location 1 is considered to correspond to the most critical condition in an installed floor since, in a properly constructed floor, the free edge at locations 3 and 4 should be supported by blocking.

6.3.2 Floor Systems with Underlayment

Floor systems D, E, F and $G$ were tested at three locations. Location lu is halfway between joists and at a point where two free edges of the plywood sheet are covered by underlayment. Location $2 u$ is at a free, unsupported edge midway between joists, and location $3 u$ is over a joist. The test results at these locations are shown in table 5.2. As expected, location $3 u$ is the strongest and Iocation $2 u$ the weakest.

The load-deflection characteristics for these loading points are compared in figure 6.13 for floor systern $\mathrm{L}$. 
Location $1 \mathrm{u}$ is considered to represent a simulation of the most critical condition, since in accordance with "FHA Minimum Property Standards" the free edge at location $2 \mathrm{u}$ should be blocked.

6.4 Relative Stiffness of the Floor Systems The load-deflection curves of the floor systems without underlayment, loaded at location 1 , are compared in figure 6.14. The ratio between applied load and measured deflection at location 1 can be taken as a measure of stiffness. System A was the least stiff. This system also had the least strength. It should be noted, that system $A$ does not meet the requirements set by "FHA Minimum Property Standards" since the thickness of the plywood was reduced by $1 / 32$ of an inch by the sanding of one surface.

The load-deflection curves of floor systems with underlayment, loaded at location $1 u$, are compared in figure 6.15 . Again, the least stiff system (E) developed the least strength.

\section{Conclusions}

1.) Out of 26 tests performed on the specimens at the weakest location likely to be encountered in a built floor, 24 exceeded the one-hour load capacity stipulated in the Operation BREAKTHROUnh criterion for concentrated-load capacity, which is hased on anticipated occupancy loads, by a substantial marein one test exactly satisfied the criterion and one test did not comply with the criterion. 
2.) For those tests that exceeded the one-hour load capacity requirement, residual deflections were generally smaller than the $1 / 16-$ in maximum stipulated in the criterion.

3.) On the basis of the data presented in reference [5], it can be concluded that in 24 out of 26 tests conducted the specimens probably met the performance level under sustained load stipulated in the criterion.

4.) The observed mode of failure under the 5/8-in diameter loaded area was punching shear or a complex combination of flexure and punching shear. Vertical compressive stresses developed under the concentrated load were not critical.

5.) Load capacity under a l-in diameter loaded area exceeded the capacity under a 5/8-in diameter loaded area by a substantial margin. Under a 1/2-in diameter loaded area vertical compressive stresses caused by a 400-1b concentrated load exceeded the compressive strength of the material.

3. Acknowledgement

The contribution of the following persons is acknowledged.

Frank A. Rankine, James F. N. Seiler and Lymus Payton from the staff of the Center for Building Technology and James Warfield, formerly on the staff of the Building Researci Division of the National Bureau of Standards. 
9. References

[1] The Building Research Division Team, E. O. Pfrang, Manager, Guide Criteria for the Evaluation of Operation BREAKTHROUGH lousing Systems dated December 1970 (NTIS Accession Numbers PB-212055, 212056, 212057, 212058).

[2] Housing and Home Finance Agency, Performance Standards, Structural and Insulation Requirements for Houses, Washington, D.C., June 1947.

[3] Boyd, J. D., Minimum Strength and Stiffness Necessary for Wooden Floors in Houses, Paper No. 34, CSIRO, Division of Forest Product Technology, Melbourne, Australia, 1964.

[4] Thorburn, H. T., Flooring Damage by Heels, Materials Research Standards, ASTM, Vol. 2, No. 9, Philadelphia, Pa., September 1962 .

[5] Wood, Lyman W., Relation of Strength of llood to Duration of Load, Forest Products Laboratory, Madison Wisconsin, December 1951.

[6] ASTM Designation E72-68, Conducting Strength Tests of Panels for Building Construction, American Society for Testing laterials, Philadelphia, Pa., 1968.

[7] ASTM Designation D 2394-69 Tests for Simulated Service Testing of Wood and Wood-Base Finish Flooring, American Society for Testing Materials, Philadelphia, Pa., 1969.

[8] National Bureau of Standards, Voluntary Product Standard PS 1-66, Softwood Plywood, Construction and Industrial, U.S. Government Printing Office, Washington, D.C., July 1970 .

[9] General Service Administration, Federal Specification, LLL-B-810 a, Building Board (Hardboard) Hard Pressed, Vegetable Fiber, Washington, D.C., July 7, 1965.

[10] West Coast Lumber Inspection Bureau (WCLIB), Rules No. 15, Grading and Dressing Rules, Portland, Oregon, January $I$, 1969.

[1I] ASTM Designation D 805-63, Veneer, PIywood and other Glue: Veneer Construction Testing, American Society for Testing Material, Philadelphia, Pa., 1963. 
[12] U.S. Department of Commerce, Commexcial Standard, CS 251 63, Washington, D.C., April 1967.

[13] ASTM Designation D 2016-65, Tests for Moisture Content of Wood, American Society for Testing Materials, Philadelphia, Pa., 1965.

[14] ASTM Designation D2395-65 T, Tests for Specific Gravity of Wood and Wood-Base Materials, American Society for Testing Materials, Philadelphia, Pa., 1965.

[15] Federal Housing Administration, Minimum Property Standards for One and Two Living Units, Washington, D.C., November 1966, as subsequently amended. 
T A B L E S 
TABLE 2.1

Number of Tests Performed

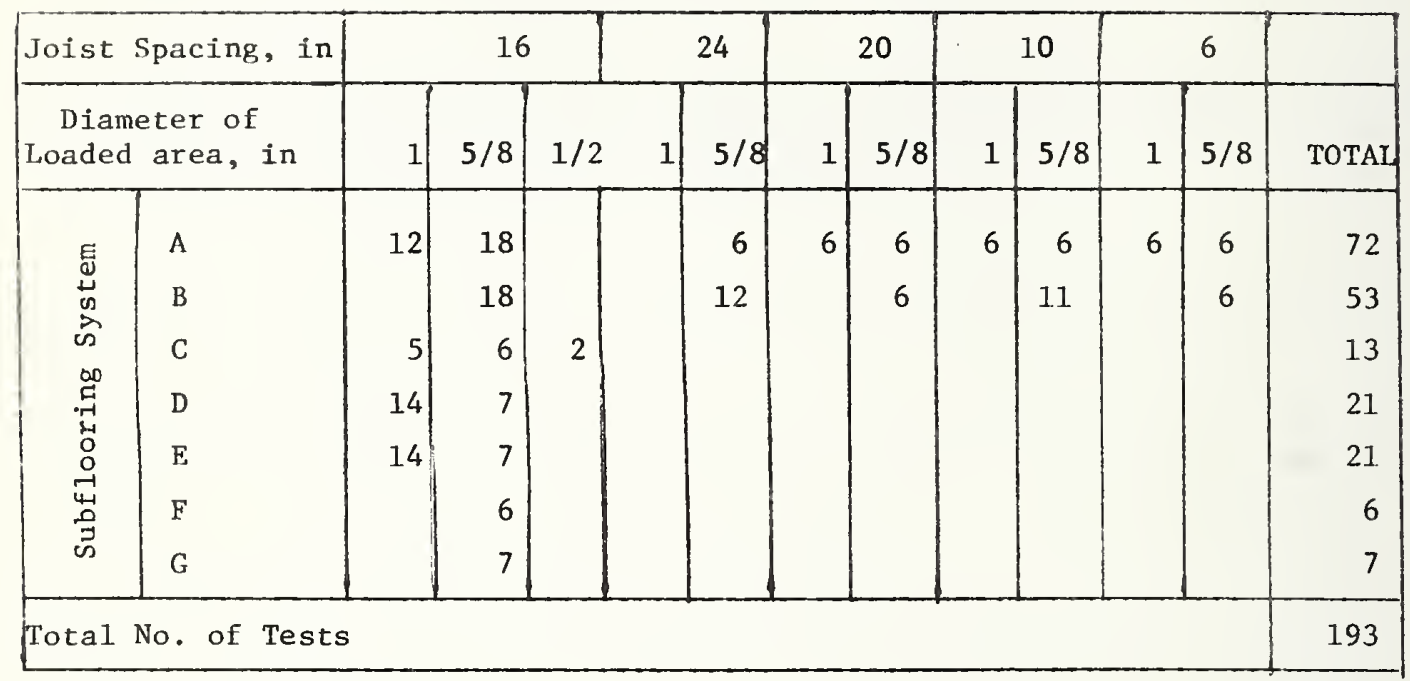

SUBFLOORING SYSTEMS :

A: 15/32-in-thick underlayment grade Southern Pine interior-type, 5-ply plywood.

B: 1/2-in-thick standard grade Southern Pine interior-type with exterior glue, 5-ply plywood.

C: 1/2-in-thick C-D grade Douglas Fir interior-type, 3-ply plywood.

D: 1/2-in-thick standard grade Douglas Fir interior-type, 3-ply a/ plywood. under 7/32-in-thick hardboard underlayment.

E: 1/2-in-thick plywood as in D under 1/4-in-thick plywood underlayment.

F: 1/2-in-thick plywood as in $C$ under 7/32-in-thick hardboard underlayment.

G: 1/2-in-thick plywood as in $C$ under 1/4-in-thick plywood underlayment.

a/ The core of this plywood was laminated giving the interior ply double thickness. 


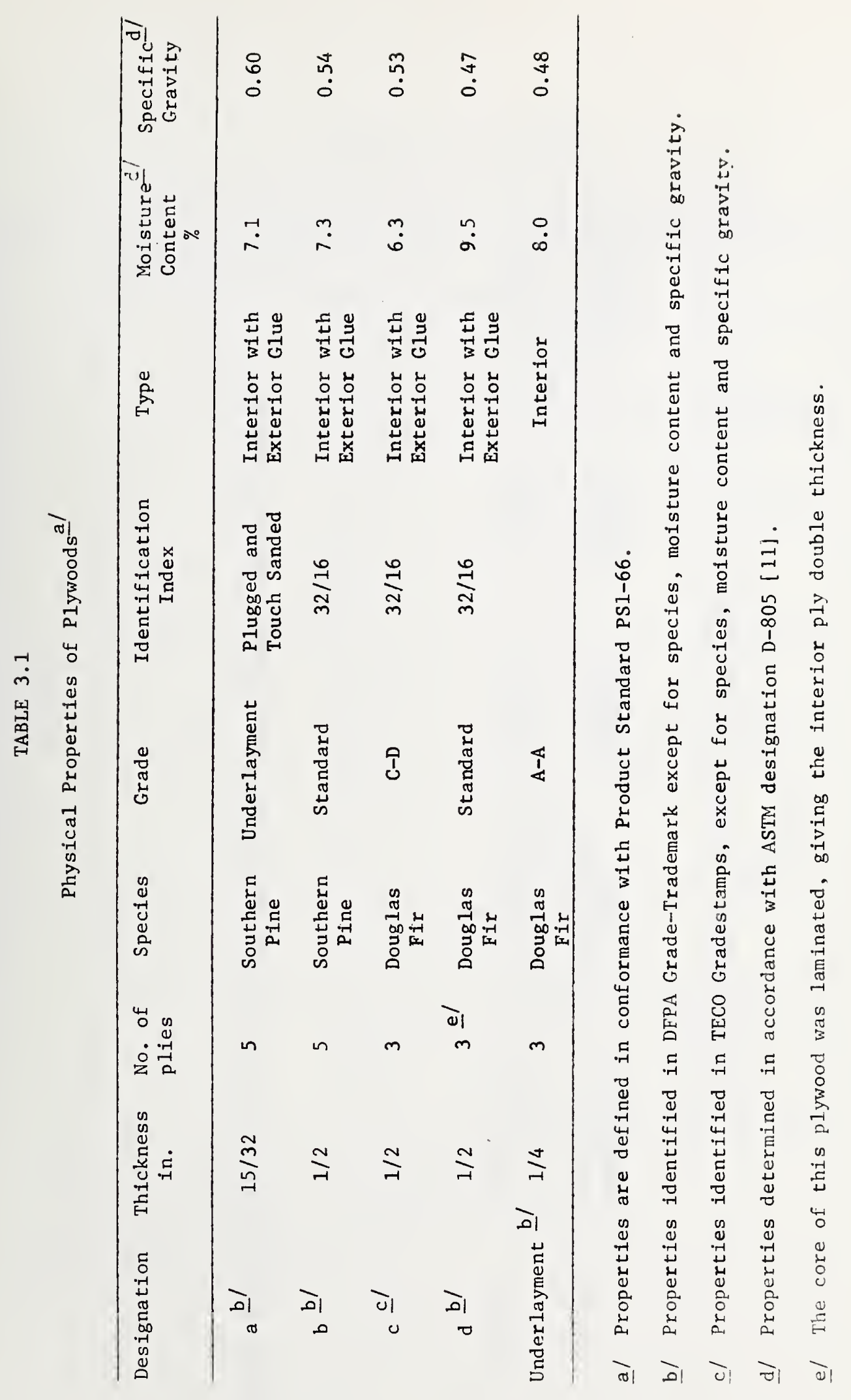




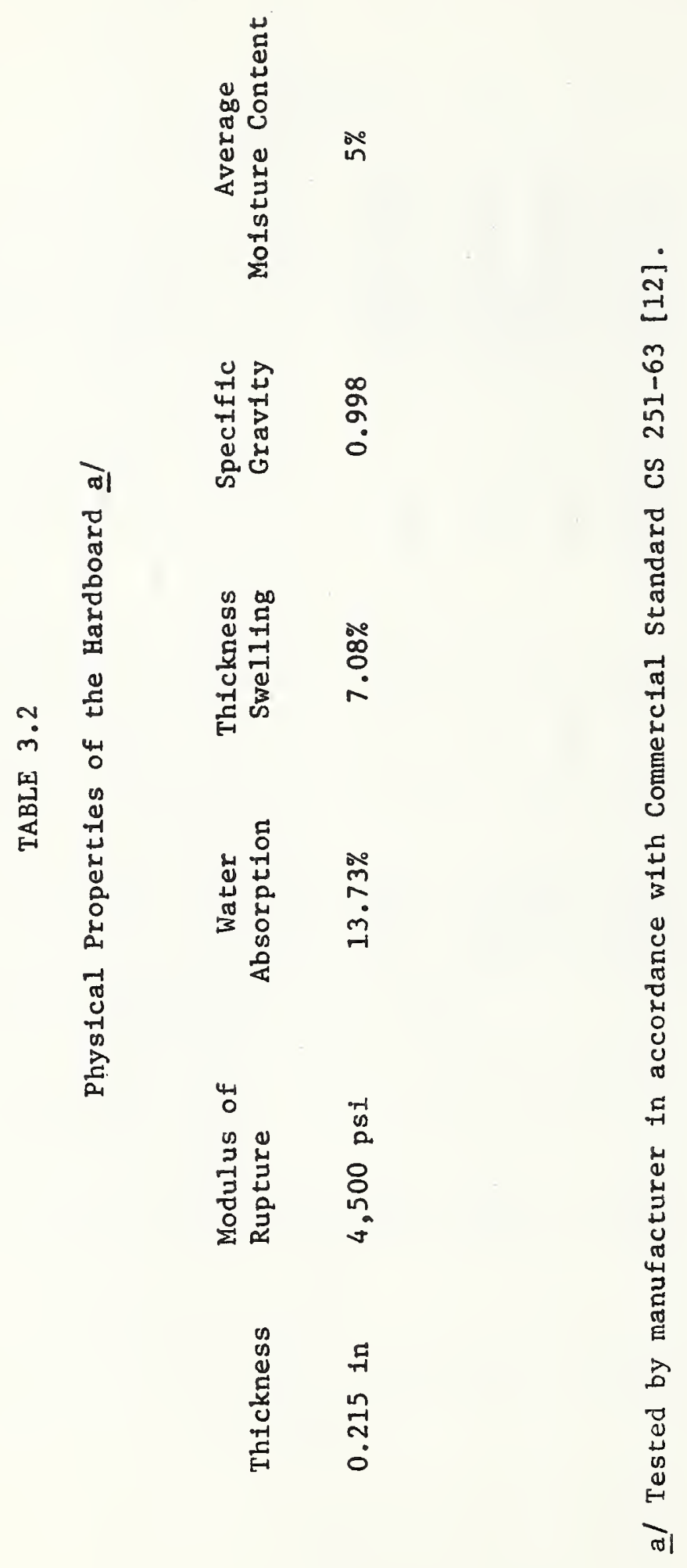


TABLE 5.1. Test Results

\begin{tabular}{|c|c|c|c|c|c|c|}
\hline $\begin{array}{l}\text { Floor } \\
\text { System }\end{array}$ & $\begin{array}{l}\text { Diameter } \\
\text { of } \\
\text { Loaded Area } \\
\text { in }\end{array}$ & $\begin{array}{l}\text { Spacing } \\
\text { of } \\
\text { Joists } \\
\text { in }\end{array}$ & $\begin{array}{c}\text { Location } \\
\text { of } \\
\text { Test }\end{array}$ & $\begin{array}{c}\text { Failure } \\
\text { Load } \\
\text { Ib }\end{array}$ & $\begin{array}{c}\text { Load Causing } \\
\text { Initial Structural } \\
\text { Damage } \\
1 \mathrm{~b}\end{array}$ & $\begin{array}{l}\text { Deflection } \\
\text { at Fallure } \\
\text { Load } \\
\text { in }\end{array}$ \\
\hline \multirow{7}{*}{$\begin{array}{c}\text { A } \\
15 / 32-i n 。 \\
5 \text { ply } \\
\text { plywood }\end{array}$} & \multirow{5}{*}{$5 / 8$} & \multirow{5}{*}{16} & 1 & $\begin{array}{l}540 \\
700 \\
620 \\
400 \\
565\end{array}$ & $\begin{array}{l}480 \\
670 \\
570 \\
400 \\
530 \text { Average }\end{array}$ & $\begin{array}{l}0.52 \\
0.54 \\
0.39 \\
0.30\end{array}$ \\
\hline & & & 2 & $\begin{array}{l}450 \\
600 \\
525\end{array}$ & $\begin{array}{l}450 \\
460 \\
455 \text { Average }\end{array}$ & $\begin{array}{l}0.34 \\
0.38\end{array}$ \\
\hline & & & 3 & $\begin{array}{l}310 \\
210 \\
440 \\
490 \\
363\end{array}$ & $\begin{array}{l}310 \\
210 \\
440 \\
460 \\
355 \text { Average }\end{array}$ & $\begin{array}{l}0.67 \\
0.51 \\
0.68 \\
0.84\end{array}$ \\
\hline & & & 4 & $\begin{array}{l}300 \\
300 \\
300\end{array}$ & $\begin{array}{l}300 \\
300 \\
300 \text { Average }\end{array}$ & $\begin{array}{l}0.61 \\
0.36\end{array}$ \\
\hline & & & 5 & $\begin{array}{l}1000 \mathrm{~b} / \\
1000 \mathrm{~b} / \\
1000 \mathrm{~b} / \\
1000 \mathrm{~b} / \\
1000 \mathrm{~b} / \\
1000 \mathrm{~b} /\end{array}$ & $\begin{array}{l}980 \\
950 \\
920 \\
---\frac{c}{c /} \\
---\frac{c}{c /}\end{array}$ & $\begin{array}{l}0.12 \mathrm{a} / \\
0.14 \mathrm{a} / \\
0.13 \mathrm{a} / \\
0.08 \mathrm{a} / \\
0.07 \text { a } / \\
0.08 \text { a } /\end{array}$ \\
\hline & \multirow[t]{2}{*}{$5 / 8$} & \multirow[t]{2}{*}{24} & 1 & $\begin{array}{l}670 \\
430 \\
820 \\
640\end{array}$ & $\begin{array}{l}460 \\
280 \\
590 \\
343 \text { Average }\end{array}$ & $\begin{array}{l}1.20 \\
0.89 \\
1.32\end{array}$ \\
\hline & & & 2 & $\begin{array}{r}1044 \\
740 \\
600 \\
795\end{array}$ & $\begin{array}{r}1044 \\
300 \\
600 \\
648 \text { Average }\end{array}$ & $\begin{array}{l}1.22 \\
.1 .14 \\
0.75\end{array}$ \\
\hline
\end{tabular}

a/ Deflection readings were taken at $10001 \mathrm{~b}$.

b/ The test was discontinued at the load level indicated.

c/ No information is available. 


\begin{tabular}{|c|c|c|c|c|c|c|}
\hline $\begin{array}{l}\text { Floor } \\
\text { System }\end{array}$ & $\begin{array}{c}\text { Diameter } \\
\text { of } \\
\text { Loaded Area } \\
\text { in }\end{array}$ & $\begin{array}{l}\text { Spacing } \\
\text { of } \\
\text { Joists } \\
\text { in }\end{array}$ & $\begin{array}{c}\text { Location } \\
\text { of } \\
\text { Test }\end{array}$ & $\begin{array}{l}\text { Failure } \\
\text { Load } \\
1 \mathrm{~b}\end{array}$ & $\begin{array}{c}\text { Load Causing } \\
\text { Initial Structural } \\
\text { Damage } \\
1 \mathrm{~b}\end{array}$ & $\begin{array}{l}\text { Deflection } \\
\text { at Failure } \\
\text { Load } \\
\text { in }\end{array}$ \\
\hline \multirow{8}{*}{ A } & \multirow{6}{*}{$5 / 8$} & \multirow[b]{2}{*}{20} & 1 & $\begin{array}{l}540 \\
610 \\
730 \\
627\end{array}$ & $\begin{array}{l}460 \\
610 \\
460 \\
510 \text { Average }\end{array}$ & $\begin{array}{l}0.63 \\
0.64 \\
0.88\end{array}$ \\
\hline & & & 2 & $\begin{array}{l}540 \\
740 \\
610 \\
630\end{array}$ & $\begin{array}{l}540 \\
450 \\
610 \\
503 \text { Average }\end{array}$ & $\begin{array}{l}0.50 \\
0.80 \\
0.61\end{array}$ \\
\hline & & \multirow[b]{2}{*}{10} & 1 & $\begin{array}{l}990 \\
910 \\
950\end{array}$ & $\begin{array}{r}890 \\
710 \\
800 \text { Average }\end{array}$ & $\begin{array}{l}0.39 \\
0.41\end{array}$ \\
\hline & & & 2 & $\begin{array}{r}1000 \\
1138 \\
960 \\
1010 \\
1027\end{array}$ & $\begin{array}{r}1000 \\
1138 \\
940 \\
950 \\
1007 \text { Average }\end{array}$ & $\begin{array}{l}0.37 \\
0.30 \mathrm{a} / \\
0.27 \\
0.31 \text { a/ }\end{array}$ \\
\hline & & \multirow[t]{2}{*}{6} & 1 & $\begin{array}{l}1082 \\
1372 \\
1227\end{array}$ & $\begin{array}{l}1082 \\
1372 \\
1227 \text { Average }\end{array}$ & $\begin{array}{l}0.25 \mathrm{a} / \\
0.18 \mathrm{a} /\end{array}$ \\
\hline & & & 2 & $\begin{array}{r}994 \\
1290 \\
1122 \\
1172 \\
1145\end{array}$ & $\frac{\begin{array}{l}994 \\
--\frac{c}{c} / \\
---\frac{c}{c /} \\
---\end{array}}{\text { Averag }}$ & $\begin{array}{l}0.28 \\
0.22 \mathrm{a} / \\
0.22 \mathrm{a} / \\
0.22 \text { al }\end{array}$ \\
\hline & \multirow[t]{2}{*}{1} & \multirow[t]{2}{*}{16} & 1 & $\begin{array}{r}1040 \\
1208 \\
1482 \\
670 \\
1065 \\
970 \\
795 \\
795 \\
1003\end{array}$ & $\begin{array}{r}640 \\
1000 \\
1000 \\
670 \\
740 \\
860 \\
700 \\
795 \\
801 \text { Average }\end{array}$ & $\begin{array}{l}0.58 \mathrm{a} / \\
0.46 \mathrm{a} / \\
0.49 \mathrm{a} / \\
0.36 \\
0.56 \text { a/ } \\
0.54 \\
0.43 \\
0.42\end{array}$ \\
\hline & & & 2 & $\begin{array}{r}1152 \\
590 \\
800 \\
590 \\
783\end{array}$ & $\begin{array}{r}1000 \\
590 \\
710 \\
590 \\
723 \text { Average }\end{array}$ & $\begin{array}{l}0.48 \text { al } \\
0.31 \\
0.62 \\
0.32\end{array}$ \\
\hline
\end{tabular}




\begin{tabular}{|c|c|c|c|c|c|c|}
\hline $\begin{array}{l}\text { Floor } \\
\text { System }\end{array}$ & $\begin{array}{c}\text { Diameter } \\
\text { of } \\
\text { Loaded Area } \\
\text { in }\end{array}$ & $\begin{array}{c}\text { Spacing } \\
\text { of } \\
\text { Joists } \\
\text { in }\end{array}$ & $\begin{array}{c}\text { Location } \\
\text { of } \\
\text { Test }\end{array}$ & $\begin{array}{l}\text { Failure } \\
\text { Load } \\
\text { lb }\end{array}$ & $\begin{array}{c}\text { Load Causing } \\
\text { Intital Structura]. } \\
\text { Damage } \\
\text { lb }\end{array}$ & $\begin{array}{l}\text { Deflection } \\
\text { at Failure } \\
\text { Load } \\
\text { in }\end{array}$ \\
\hline \multirow{6}{*}{ A } & \multirow{6}{*}{1} & \multirow[t]{2}{*}{20} & 1 & $\begin{array}{l}845 \\
860 \\
530 \\
745\end{array}$ & $\begin{array}{l}845 \\
860 \\
370 \\
558 \text { Average }\end{array}$ & $\begin{array}{l}0.64 \\
0.74 \\
0.51\end{array}$ \\
\hline & & & 2 & $\begin{array}{r}850 \\
1242 \\
1264 \\
1119\end{array}$ & $\begin{array}{r}660 \\
1000 \\
560 \\
740 \text { Average }\end{array}$ & $\begin{array}{l}0.66 \\
0.87 \mathrm{al} \\
0.84 \mathrm{a} /\end{array}$ \\
\hline & & \multirow[t]{2}{*}{10} & 1 & $\begin{array}{l}1788 \\
1706 \\
1747\end{array}$ & $\frac{\ldots-c /}{-\cdots c /}$ & $\begin{array}{ll}-\cdots & c / \\
\cdots & c l\end{array}$ \\
\hline & & & 2 & $\begin{array}{l}1662 \\
1182 \\
1726 \\
1268 \\
1460\end{array}$ & $\begin{array}{l}---\frac{c}{c} / \\
---\frac{c}{c} / \\
---\frac{c}{c} / \\
-- \text { Average }\end{array}$ & 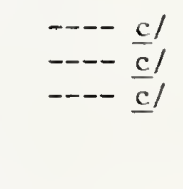 \\
\hline & & \multirow[t]{2}{*}{6} & 1 & $\begin{array}{l}1750 \\
1740 \\
1745\end{array}$ & $\frac{---\frac{c}{c} /}{---c /}$ & $-\cdots \frac{c}{c} l$ \\
\hline & & & 2 & $\begin{array}{l}1546 \\
1564 \\
1508 \\
1584 \\
1551\end{array}$ & \begin{tabular}{l|}
$---\frac{c}{c} /$ \\
$---\frac{c}{c} /$ \\
$---\frac{c}{c} /$ \\
--
\end{tabular} & $\begin{array}{l}-\cdots \frac{c}{c /} \\
\cdots--\frac{c}{c /} \\
\cdots-- \\
\cdots\end{array}$ \\
\hline \multirow{3}{*}{$\begin{array}{l}\text { B } \\
1 / 2-i n \text {. } \\
5 \text { ply } \\
\text { plywood }\end{array}$} & \multirow{3}{*}{$5 / 8$} & \multirow{3}{*}{16} & 1 & $\begin{array}{l}895 \\
860 \\
825 \\
600 \\
795\end{array}$ & \begin{tabular}{l|}
895 \\
660 \\
810 \\
600 \\
741 Average
\end{tabular} & $\begin{array}{l}0.51 \\
0.61 \\
0.61 \\
0.40\end{array}$ \\
\hline & & & 2 & $\begin{array}{l}730 \\
790 \\
760\end{array}$ & $\begin{array}{l}700 \\
790 \\
745 \text { Average }\end{array}$ & $\begin{array}{l}0.43 \\
0.51\end{array}$ \\
\hline & & & 3 & $\begin{array}{l}290 \\
480 \\
425 \\
590 \\
446\end{array}$ & $\begin{array}{l}290 \\
470 \\
360 \\
590 \\
428 \text { Average }\end{array}$ & $\begin{array}{l}0.43 \\
0.68 \\
0.68 \\
0.79\end{array}$ \\
\hline
\end{tabular}


4

\begin{tabular}{|c|c|c|c|c|c|c|}
\hline $\begin{array}{l}\text { Plowr } \\
\text { System }\end{array}$ & $\begin{array}{l}\text { Diameter } \\
\text { of } \\
\text { Loaded Area } \\
\text { in }\end{array}$ & $\begin{array}{l}\text { Spacing } \\
\text { of } \\
\text { Joists } \\
\text { in }\end{array}$ & $\begin{array}{c}\text { Location } \\
\text { of } \\
\text { Test }\end{array}$ & $\begin{array}{l}\text { Failure } \\
\text { Load } \\
\text { 1b }\end{array}$ & $\begin{array}{c}\text { Load Causing } \\
\text { Initial Structural } \\
\text { Damage } \\
1 \mathrm{~b}\end{array}$ & $\begin{array}{l}\text { Deflection } \\
\text { at Failure } \\
\text { Load } \\
\text { in }\end{array}$ \\
\hline \multirow{7}{*}{ B } & \multirow{7}{*}{$5 / 8$} & \multirow{2}{*}{16} & 4 & $\begin{array}{r}440 \\
634 \\
537\end{array}$ & $\begin{array}{l}440 \\
634 \\
537 \text { Average }\end{array}$ & $\begin{array}{l}0.57 \\
0.68\end{array}$ \\
\hline & & & 5 & $\begin{array}{r}840 \\
1000 \mathrm{~b} / \\
950 \\
1000 \mathrm{~b} / \\
1000 \frac{\mathrm{b}}{\mathrm{b}} / \\
1000 / \\
\end{array}$ & $\begin{array}{l}840 \\
--c \text { cl } \\
950 \\
630 \\
---c \text { cl } \\
-\cdots-c /\end{array}$ & $\begin{array}{l}0.14 \\
0.12 \mathrm{a} / \\
0.13 \\
0.14 \mathrm{a} / \\
0.11 \mathrm{a} / \\
0.11 \mathrm{a} / \\
\end{array}$ \\
\hline & & \multirow[t]{2}{*}{24} & 1 & $\begin{array}{l}890 \\
945 \\
730 \\
910 \\
652 \\
640 \\
600 \\
920 \\
748\end{array}$ & $\begin{array}{l}780 \\
790 \\
640 \\
910 \\
360 \\
600 \\
600 \\
500 \\
640 \text { Average }\end{array}$ & $\begin{array}{l}1.29 \\
1.29 \\
1.20 \\
1.25 \\
1.06 \\
1.08 \\
0.94 \\
1.27\end{array}$ \\
\hline & & & 2 & $\begin{array}{l}680 \\
670 \\
795 \\
770 \\
729\end{array}$ & $\begin{array}{l}660 \\
670 \\
795 \\
770 \\
724 \text { Average }\end{array}$ & $\begin{array}{l}0.81 \\
1.07 \\
0.97 \\
0.92\end{array}$ \\
\hline & & \multirow[t]{2}{*}{20} & 1 & $\begin{array}{l}785 \\
634 \\
800 \\
740\end{array}$ & $\begin{array}{l}785 \\
634 \\
630 \\
683 \text { 4verage }\end{array}$ & $\begin{array}{l}0.79 \\
0.59 \\
0.90\end{array}$ \\
\hline & & & 2 & $\begin{array}{l}990 \\
810 \\
810 \\
870\end{array}$ & $\begin{array}{l}890 \\
660 \\
810 \\
787 \text { Average }\end{array}$ & $\begin{array}{l}0.78 \\
0.71 \\
0.61\end{array}$ \\
\hline & & 10 & 1 & $\begin{array}{r}940 \\
650 \\
830 \\
1126 \\
900 \\
889\end{array}$ & $\begin{array}{l}690 \\
650 \\
550 \\
570 \\
900 \\
672 \text { Average }\end{array}$ & $\begin{array}{l}0.39 \\
0.24 \\
0.31 \\
0.44 \text { al } \\
0.25\end{array}$ \\
\hline
\end{tabular}




\begin{tabular}{|c|c|c|c|c|c|c|}
\hline $\begin{array}{l}\text { lil wor } \\
\text { System }\end{array}$ & $\begin{array}{l}\text { Diameler } \\
\text { of } \\
\text { Loaded Area } \\
\text { in }\end{array}$ & $\begin{array}{l}\text { Spaclng } \\
\text { of } \\
\text { Joists } \\
\text { in }\end{array}$ & $\begin{array}{c}\text { Localion } \\
\text { of } \\
\text { Test }\end{array}$ & $\begin{array}{l}\text { Fallure } \\
\text { Load } \\
\text { 1b }\end{array}$ & $\begin{array}{c}\text { load Causing } \\
\text { Initial Structural } \\
\text { Damage } \\
\text { lb }\end{array}$ & $\begin{array}{l}\text { Drflection } \\
\text { at Fatlure } \\
\text { Load } \\
\text { in }\end{array}$ \\
\hline \multirow{4}{*}{ B } & \multirow{4}{*}{$5 / 8$} & \multirow[t]{2}{*}{10} & \multirow[t]{2}{*}{2} & $\begin{array}{l}660 \\
960 \\
660 \\
840 \\
800 \\
990 \\
\end{array}$ & $\begin{array}{l}620 \\
820 \\
660 \\
830 \\
800 \\
670 \\
\end{array}$ & \multirow[t]{2}{*}{$\begin{array}{l}0.36 \\
0.38 \\
0.23 \\
0.31 \\
0.27 \\
0.35\end{array}$} \\
\hline & & & & 818 & 733 Average & \\
\hline & & \multirow[t]{2}{*}{6} & 1 & $\begin{array}{r}830 \\
1012 \\
921\end{array}$ & $\begin{array}{r}680 \\
1012 \\
846 \text { Average }\end{array}$ & $\begin{array}{l}0.20 \\
0.28 \mathrm{a} /\end{array}$ \\
\hline & & & 2 & $\begin{array}{l}790 \\
810 \\
938 \\
975 \\
878\end{array}$ & $\begin{array}{l}790 \\
810 \\
938 \\
830 \\
842 \text { Average }\end{array}$ & $\begin{array}{l}0.17 \\
0.18 \\
0.32 \\
0.29\end{array}$ \\
\hline \multirow{8}{*}{$\begin{array}{c}\text { C } \\
\text { 1/2-in. } \\
\text { 3-ply } \\
\text { plywood }\end{array}$} & \multirow{4}{*}{$5 / 8$} & \multirow{4}{*}{16} & 1 & 580 & 540 & 0.31 \\
\hline & & & 2 & 770 & 770 & 0.37 \\
\hline & & & 3 & $\begin{array}{l}250 \\
380 \\
315\end{array}$ & $\begin{array}{l}250 \\
380 \\
315 \text { Average }\end{array}$ & $\begin{array}{l}0.31 \\
0.62\end{array}$ \\
\hline & & & 5 & $\begin{array}{l}1000 \mathrm{~b} / \\
1000 \mathrm{~b} /\end{array}$ & $\begin{array}{l}520 \\
470 \\
495 \text { Average }\end{array}$ & $\begin{array}{l}0.12 \mathrm{a} / \\
0.13 \mathrm{a} /\end{array}$ \\
\hline & $1 / 2$ & 16 & 5 & $\begin{array}{l}1000 \mathrm{~b} / \\
1000 \mathrm{~b} / \\
\end{array}$ & $\begin{array}{l}280 \\
700 \\
490 \text { Average }\end{array}$ & $\begin{array}{l}0.21 \mathrm{a} / \\
0.19 \mathrm{a} /\end{array}$ \\
\hline & \multirow[t]{3}{*}{1} & \multirow[t]{3}{*}{16} & 1 & $\begin{array}{r}710 \\
710 \\
710\end{array}$ & $\begin{array}{l}620 \\
630 \\
625 \text { Average }\end{array}$ & $\begin{array}{l}0.59 \\
0.37\end{array}$ \\
\hline & & & 3 & $\begin{array}{l}420 \\
660 \\
540\end{array}$ & $\begin{array}{l}350 \\
460 \\
405 \text { Average }\end{array}$ & $\begin{array}{l}0.76 \\
0.85\end{array}$ \\
\hline & & & 4 & 400 & 350 & 0.45 \\
\hline
\end{tabular}




\begin{tabular}{|c|c|c|c|c|c|c|}
\hline $\begin{array}{r}\text { Floor } \\
\text { System }\end{array}$ & $\begin{array}{l}\text { Diameter } \\
\text { of } \\
\text { Loaded Area } \\
\text { in }\end{array}$ & $\begin{array}{l}\text { Spacing } \\
\text { of } \\
\text { Joists } \\
\text { in }\end{array}$ & $\begin{array}{c}\text { Location } \\
\text { of } \\
\text { Test. }\end{array}$ & $\begin{array}{l}\text { Failure } \\
\text { Load } \\
\text { 1b }\end{array}$ & $\begin{array}{c}\text { Load Causing } \\
\text { Initia1 Structura1 } \\
\text { Damage } \\
1 \mathrm{~b}\end{array}$ & $\begin{array}{l}\text { Deflection } \\
\text { at Failure } \\
\text { Load } \\
\text { in }\end{array}$ \\
\hline \multirow{6}{*}{$\begin{array}{c}\text { D } \\
\text { 1/2-in. } \\
\text { 3-ply } \\
\text { plywood }\end{array}$} & \multirow[t]{3}{*}{$5 / 8$} & \multirow[t]{3}{*}{16} & $1 \mathrm{u}$ & $\begin{array}{l}780 \\
675 \\
695 \\
680 \\
708\end{array}$ & $\begin{array}{l}570 \\
620 \\
660 \\
480 \\
583 \text { Average }\end{array}$ & $\begin{array}{l}1.21 \\
0.53 \\
0.57 \\
0.71\end{array}$ \\
\hline & & & $2 u$ & 568 & 330 & $\cdots \leq l$ \\
\hline & & & $3 u$ & $\begin{array}{l}1000 \mathrm{~b} / \\
1000 \mathrm{~b} /\end{array}$ & $\cdots \frac{c l}{c-.}$ & $\begin{array}{l}0.18 \mathrm{a} / \\
0.18 \mathrm{a} /\end{array}$ \\
\hline & \multirow[t]{3}{*}{1} & \multirow[t]{3}{*}{16} & $1 \mathrm{u}$ & $\begin{array}{r}1025 \\
1006 \\
1002 \\
1008 \\
1064 \\
985 \\
1015\end{array}$ & $\begin{array}{r}910 \\
730 \\
1000 \\
1008 \\
1064 \\
960 \\
945 \text { Average }\end{array}$ & $\begin{array}{l}0.74 \text { a } / \\
0.70 \\
0.71 \\
0.70 \\
0.71 \\
0.80\end{array}$ \\
\hline & & & $2 u$ & $\begin{array}{l}800 \\
640 \\
700 \\
660 \\
700\end{array}$ & $\begin{array}{l}570 \\
440 \\
570 \\
500 \\
520 \text { Average }\end{array}$ & $\begin{array}{l}1.32 \\
1.31 \\
1.50 \\
1.50\end{array}$ \\
\hline & & & $3 u$ & $\begin{array}{l}1000 \mathrm{~b} / \\
1000 \mathrm{~b} / \\
1000 \mathrm{~b} / \\
1000 \mathrm{~b} /\end{array}$ & $\begin{array}{l}-\cdots \frac{c}{c} / \\
\cdots-\frac{c}{c} / \\
\cdots \\
-\cdots\end{array}$ & $\begin{array}{l}0.09 \mathrm{a} / \\
0.09 \mathrm{a} / \\
0.11 \mathrm{a} / \\
0.11 \mathrm{a} /\end{array}$ \\
\hline \multirow{3}{*}{$\begin{array}{c}\text { E } \\
\text { 1/2-in。 } \\
3 \text {-ply. } \\
\text { plywood } \\
+1 / 4-i n 。 \\
\text { plywood }\end{array}$} & \multirow{3}{*}{$5 / 8$} & \multirow{3}{*}{16} & $1 \mathrm{u}$ & $\begin{array}{l}410 \\
542 \\
540 \\
497\end{array}$ & $\begin{array}{l}360 \\
542 \\
540 \\
481 \text { Average }\end{array}$ & $\begin{array}{l}0.51 \\
0.53 \\
0.52\end{array}$ \\
\hline & & & $2 u$ & $\begin{array}{l}400 \\
450 \\
425\end{array}$ & $\begin{array}{l}390 \\
420 \\
405 \text { Average }\end{array}$ & $\begin{array}{l}0.73 \\
0.96\end{array}$ \\
\hline & & & $3 u$ & $\begin{array}{l}670 \\
880 \\
775\end{array}$ & $\begin{array}{l}670 \\
810 \\
740 \text { Average }\end{array}$ & $\begin{array}{l}0.22 \\
0.18\end{array}$ \\
\hline
\end{tabular}




\begin{tabular}{|c|c|c|c|c|c|c|}
\hline $\begin{array}{l}\text { Floor } \\
\text { Systems }\end{array}$ & $\begin{array}{l}\text { Diameter } \\
\text { of } \\
\text { Loaded Area } \\
\text { in }\end{array}$ & $\begin{array}{l}\text { Spacing } \\
\text { of } \\
\text { Joist } \\
\text { in }\end{array}$ & $\begin{array}{c}\text { Location } \\
\text { of } \\
\text { Test }\end{array}$ & $\begin{array}{l}\text { Failure } \\
\text { Load } \\
1 b\end{array}$ & $\begin{array}{c}\text { Load Causing } \\
\text { Initial Structural } \\
\text { Damage } \\
\text { lb }\end{array}$ & $\begin{array}{l}\text { Deflection } \\
\text { at Failure } \\
\text { Load } \\
\text { in }\end{array}$ \\
\hline \multirow[t]{3}{*}{$E$} & \multirow[t]{3}{*}{1} & \multirow[t]{3}{*}{16} & Iu & $\begin{array}{r}1002 \\
1104 \\
890 \\
830 \\
670 \\
700 \\
866\end{array}$ & $\begin{array}{r}1002 \\
1000 \\
890 \\
830 \\
500 \\
550 \\
795 \text { A verage }\end{array}$ & $\begin{array}{l}0.65 \\
0.63 \mathrm{al} \\
0.63 \\
0.58 \\
0.50 \\
0.70\end{array}$ \\
\hline & & & $2 u$ & $\begin{array}{l}820 \\
380 \\
670 \\
545 \\
604\end{array}$ & $\begin{array}{r}630 \\
380 \\
530 \\
240 \\
445 \text { Average }\end{array}$ & $\begin{array}{l}1.31 \\
0.63 \\
1.48 \\
1.50\end{array}$ \\
\hline & & & $3 u$ & $\begin{array}{l}1000 \frac{b /}{b /} \\
1000 \frac{b}{b} / \\
1000 \frac{b}{b} /\end{array}$ & $\begin{array}{l}--\frac{c}{c} / \\
---\frac{c}{c /} \\
-\cdots \\
--\frac{c}{c} /\end{array}$ & $\begin{array}{l}0.16 \mathrm{a} / \\
0.16 \mathrm{a} / \\
0.21 \mathrm{a} / \\
0.21 \mathrm{a} /\end{array}$ \\
\hline \multirow{3}{*}{$\begin{array}{c}F \\
1 / 2-i n . \\
\text { 3-ply } \\
\text { plywood } \\
+1 / 4-i n . \\
\text { plywood }\end{array}$} & \multirow{3}{*}{$\begin{array}{c}5 / 8 \\
+7 / 32-i n 。 \\
\text { hardboard }\end{array}$} & \multirow[t]{3}{*}{16} & $1 \mathrm{u}$ & $\begin{array}{l}950 \\
890 \\
920\end{array}$ & $\begin{array}{l}950 \\
\frac{860}{905} \text { Average }\end{array}$ & $\begin{array}{l}0.55 \\
0.58\end{array}$ \\
\hline & & & $2 u$ & $\begin{array}{l}420 \\
310 \\
365\end{array}$ & $\begin{array}{l}420 \\
290 \\
355 \text { Average }\end{array}$ & $\begin{array}{l}0.66 \\
0.39\end{array}$ \\
\hline & & & $3 u$ & $\begin{array}{l}1000 \mathrm{~b} / \\
1000 \mathrm{~b} /\end{array}$ & $\begin{array}{ll}--\frac{c}{c} \\
---\end{array}$ & $\begin{array}{l}0.12 \mathrm{a} / \\
0.12 \mathrm{a} /\end{array}$ \\
\hline \multirow{3}{*}{$\begin{array}{c}\text { G } \\
1 / 2-i n . \\
3-p 1 y \\
\text { plywood } \\
+1 / 4-i n . \\
\text { plywood }\end{array}$} & \multirow{3}{*}{$5 / 8$} & \multirow{3}{*}{16} & lu & $\begin{array}{l}720 \\
860 \\
770 \\
783\end{array}$ & $\begin{array}{l}670 \\
680 \\
690 \\
680 \text { Average }\end{array}$ & $\begin{array}{l}0.43 \\
0.56 \\
0.56\end{array}$ \\
\hline & & & $2 u$ & $\begin{array}{l}350 \\
370 \\
360\end{array}$ & $\begin{array}{l}300 \\
370 \\
335 \text { Averige }\end{array}$ & $\begin{array}{l}0.55 \\
0.53\end{array}$ \\
\hline & & & $3 u$ & $\begin{array}{l}1000 \mathrm{~b} / \\
1000 \mathrm{~b} /\end{array}$ & $\begin{array}{ll}-- & 1 / \\
-- & 0 /\end{array}$ & $\begin{array}{l}0.20 \\
0.19\end{array}$ \\
\hline
\end{tabular}


TABLE 5.2

Summary of Average Test Results for Specimens with 16-in Joist Spacing

\begin{tabular}{|c|c|c|c|c|c|}
\hline & & \multicolumn{2}{|c|}{ 5/8-in Diameter Area } & \multicolumn{2}{|c|}{ 1-in Diameter Area } \\
\hline $\begin{array}{c}\text { Floor } \\
\text { Systems }\end{array}$ & $\begin{array}{c}\text { Location } \\
\text { of } \\
\text { Test }\end{array}$ & $\begin{array}{c}\text { Average } \\
\text { Failure } \\
\text { Load } \\
\text { 1b }\end{array}$ & $\begin{array}{c}\text { Average Load } \\
\text { Causing Initial } \\
\text { Structural Damage } \\
\text { 1b }\end{array}$ & $\begin{array}{c}\text { Average } \\
\text { Failure } \\
\text { Load } \\
\text { lb }\end{array}$ & $\begin{array}{c}\text { Average Load } \\
\text { Causing Initial } \\
\text { Structural Damage } \\
\text { lb }\end{array}$ \\
\hline A & $\begin{array}{l}1 \\
2 \\
3 \\
4 \\
5\end{array}$ & $\begin{array}{c}565 \\
525 \\
363 \\
300 \\
1000+\end{array}$ & $\begin{array}{l}530 \\
455 \\
355 \\
300 \\
975+\end{array}$ & $\begin{array}{r}1003 \\
783\end{array}$ & $\begin{array}{l}801 \\
723\end{array}$ \\
\hline B & $\begin{array}{l}1 \\
2 \\
3 \\
4 \\
5\end{array}$ & $\begin{array}{r}795 \\
760 \\
446 \\
537 \\
1000+\end{array}$ & $\begin{array}{l}745 \\
745 \\
428 \\
537 \\
903+\end{array}$ & & \\
\hline $\mathrm{C}$ & $\begin{array}{l}1 \\
2 \\
3 \\
4 \\
5\end{array}$ & $\begin{array}{r}580 \\
770 \\
315 \\
1000+\end{array}$ & $\begin{array}{l}540 \\
770 \\
315 \\
495\end{array}$ & $\begin{array}{l}710 \\
540 \\
400\end{array}$ & $\begin{array}{l}625 \\
405 \\
350\end{array}$ \\
\hline $\mathrm{D}$ & $\begin{array}{l}1 u \\
2 u \\
3 u\end{array}$ & $\begin{array}{c}708 \\
568 \\
1000+\end{array}$ & $\begin{array}{l}583 \\
330\end{array}$ & $\begin{array}{c}1015 \\
700 \\
1000+\end{array}$ & $\begin{array}{l}945 \\
520\end{array}$ \\
\hline$E$ & $\begin{array}{l}1 u \\
2 u \\
3 u\end{array}$ & $\begin{array}{l}497 \\
425 \\
775\end{array}$ & $\begin{array}{l}481 \\
405 \\
740\end{array}$ & $\begin{array}{c}866 \\
604 \\
1000+\end{array}$ & $\begin{array}{l}795 \\
445\end{array}$ \\
\hline $\mathrm{F}$ & $\begin{array}{l}1 u \\
2 u \\
3 u\end{array}$ & $\begin{array}{c}920 \\
365 \\
1000+\end{array}$ & $\begin{array}{l}905 \\
355\end{array}$ & & \\
\hline G & $\begin{array}{l}1 u \\
2 u \\
3 u\end{array}$ & $\begin{array}{c}783 \\
360 \\
1000+\end{array}$ & $\begin{array}{l}680 \\
335\end{array}$ & & \\
\hline
\end{tabular}


F I G U R E S 


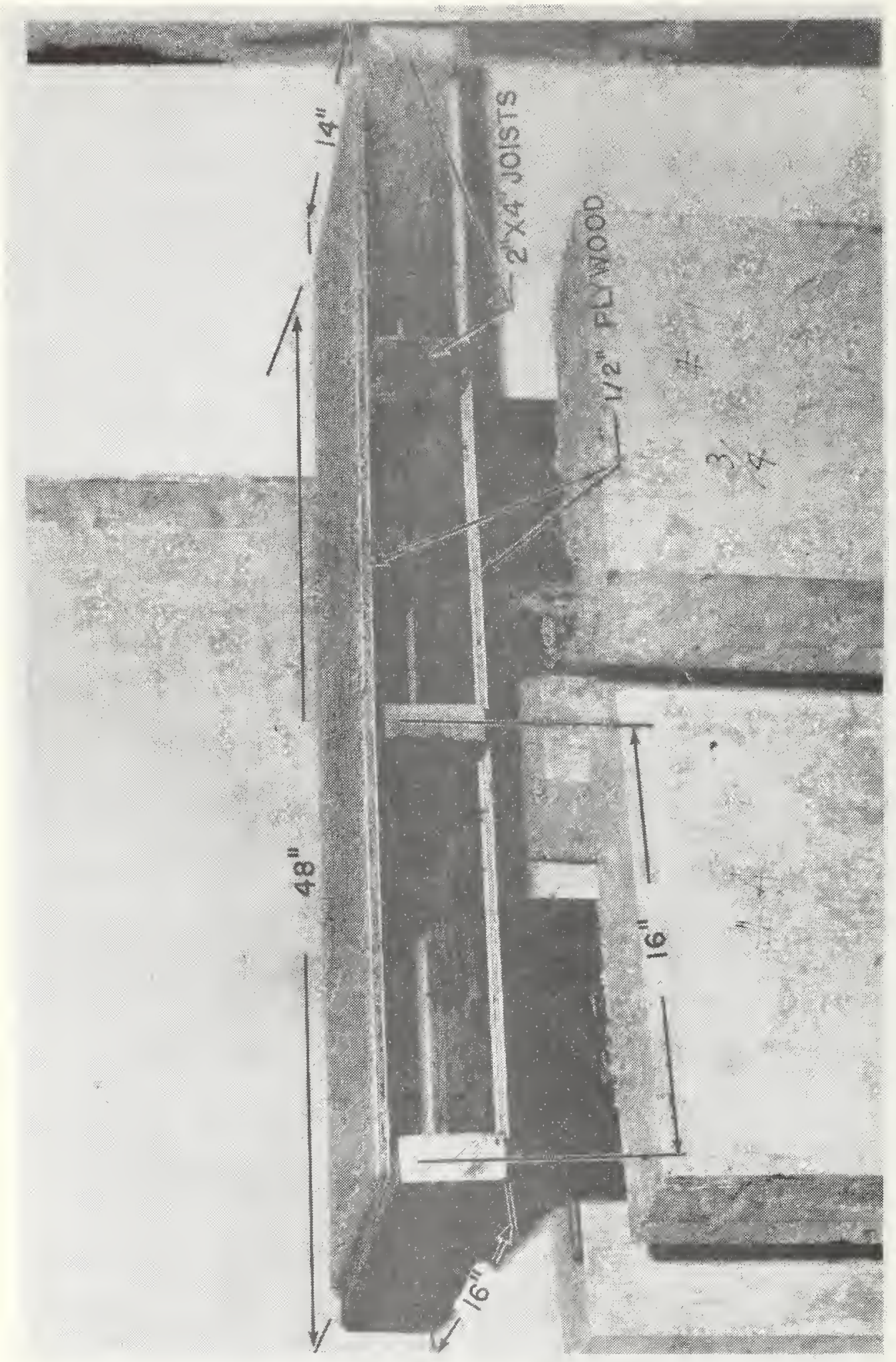

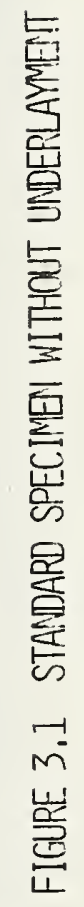




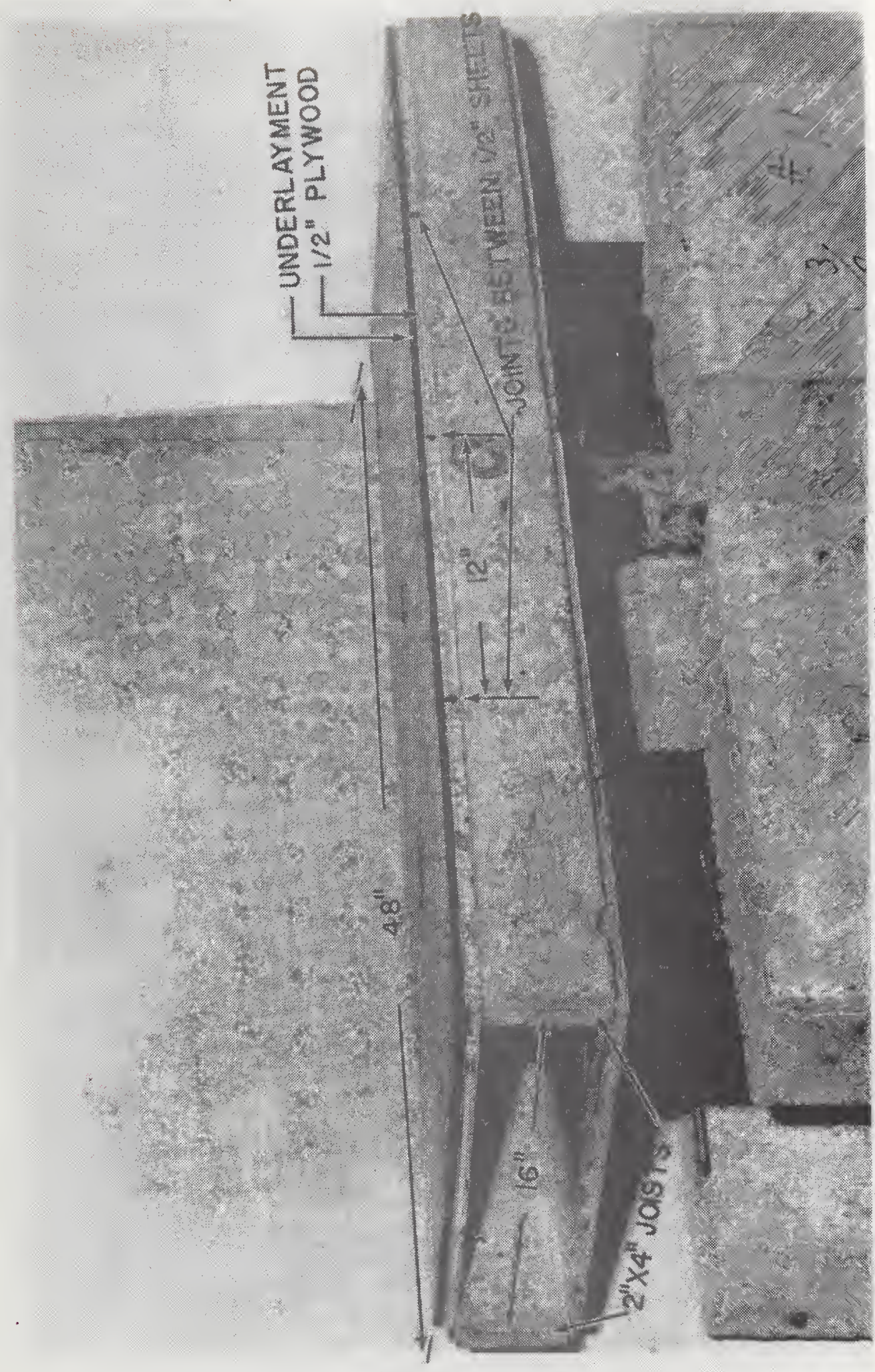

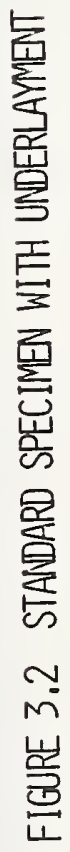




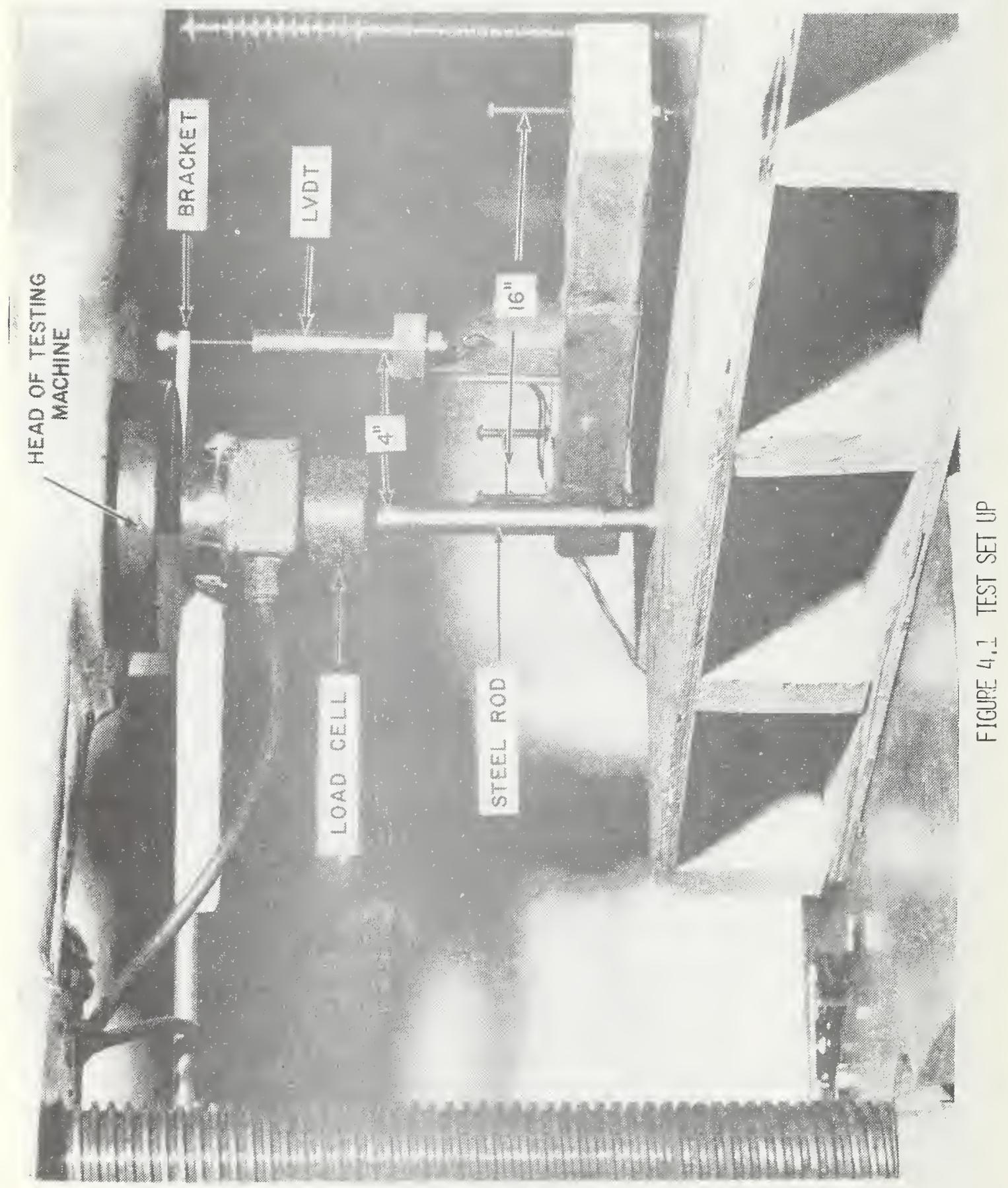




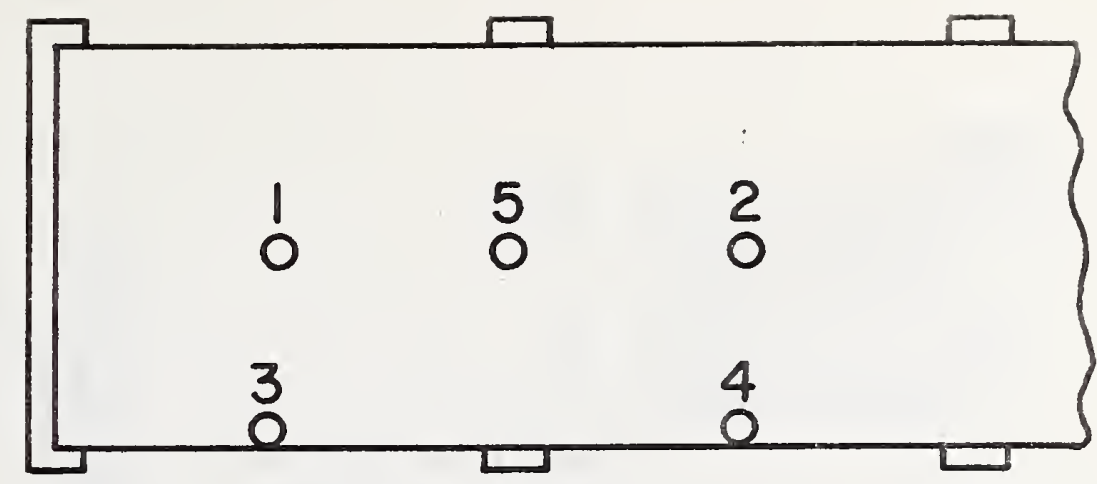

(a) SPECIMEN WITHOUT UNDERLAYMENT

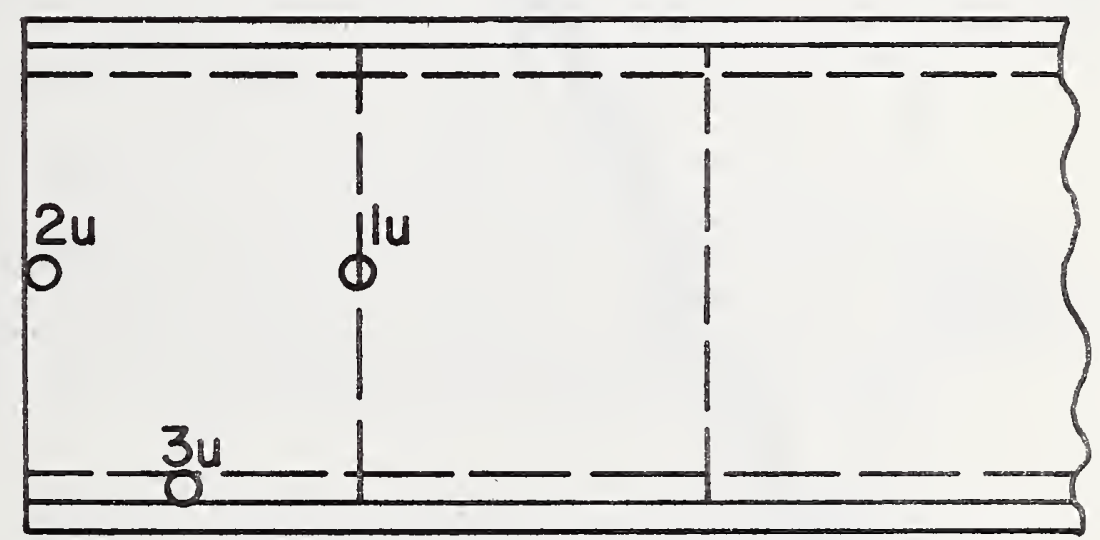

(b) SPECIMEN WITH UNDERLAYMENT

FIGURE 5.1 LOCATION OF TEST POINTS 


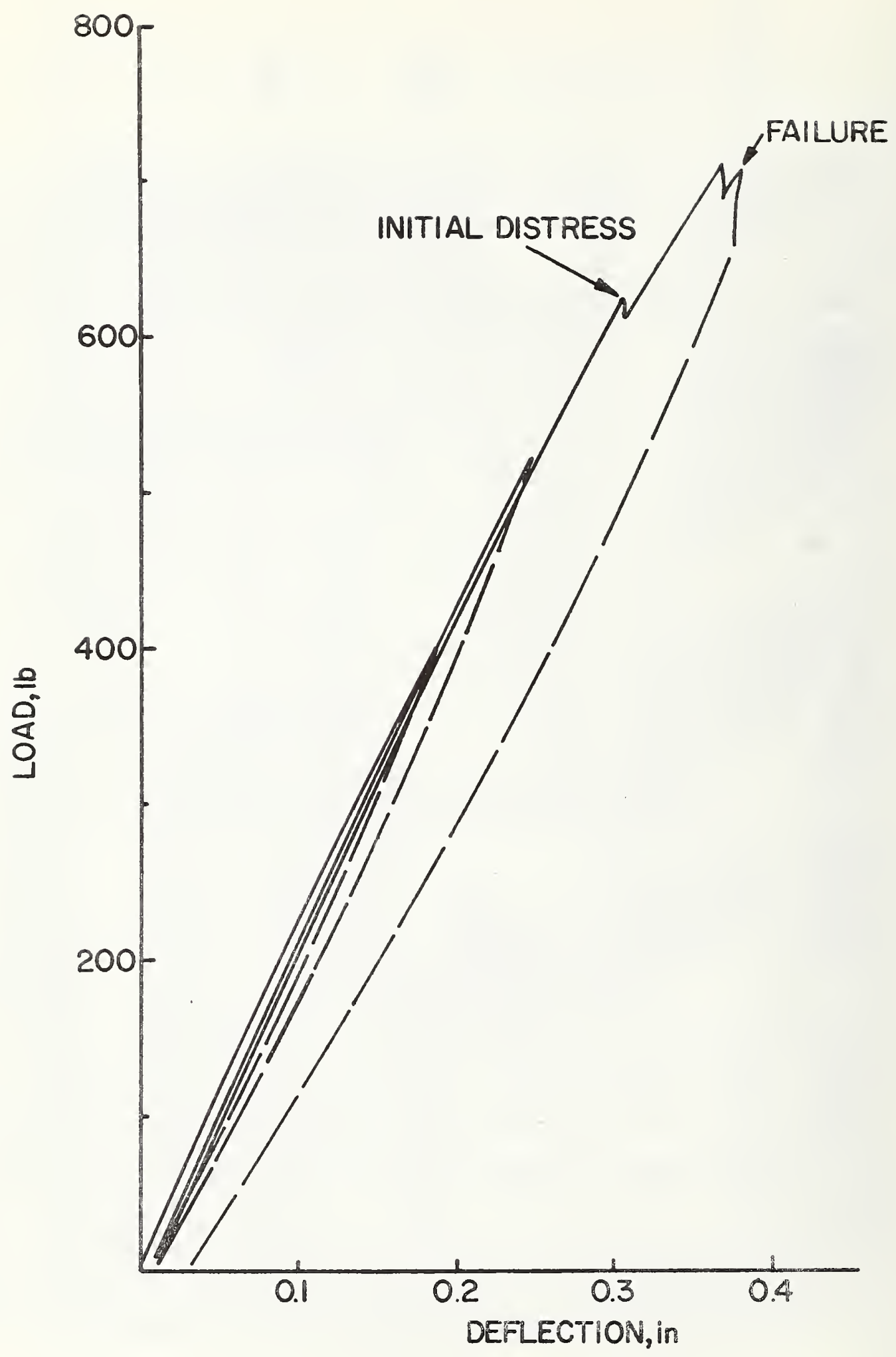

FIGURE 5.2 INTERPRETATION OF TEST RESULTS 


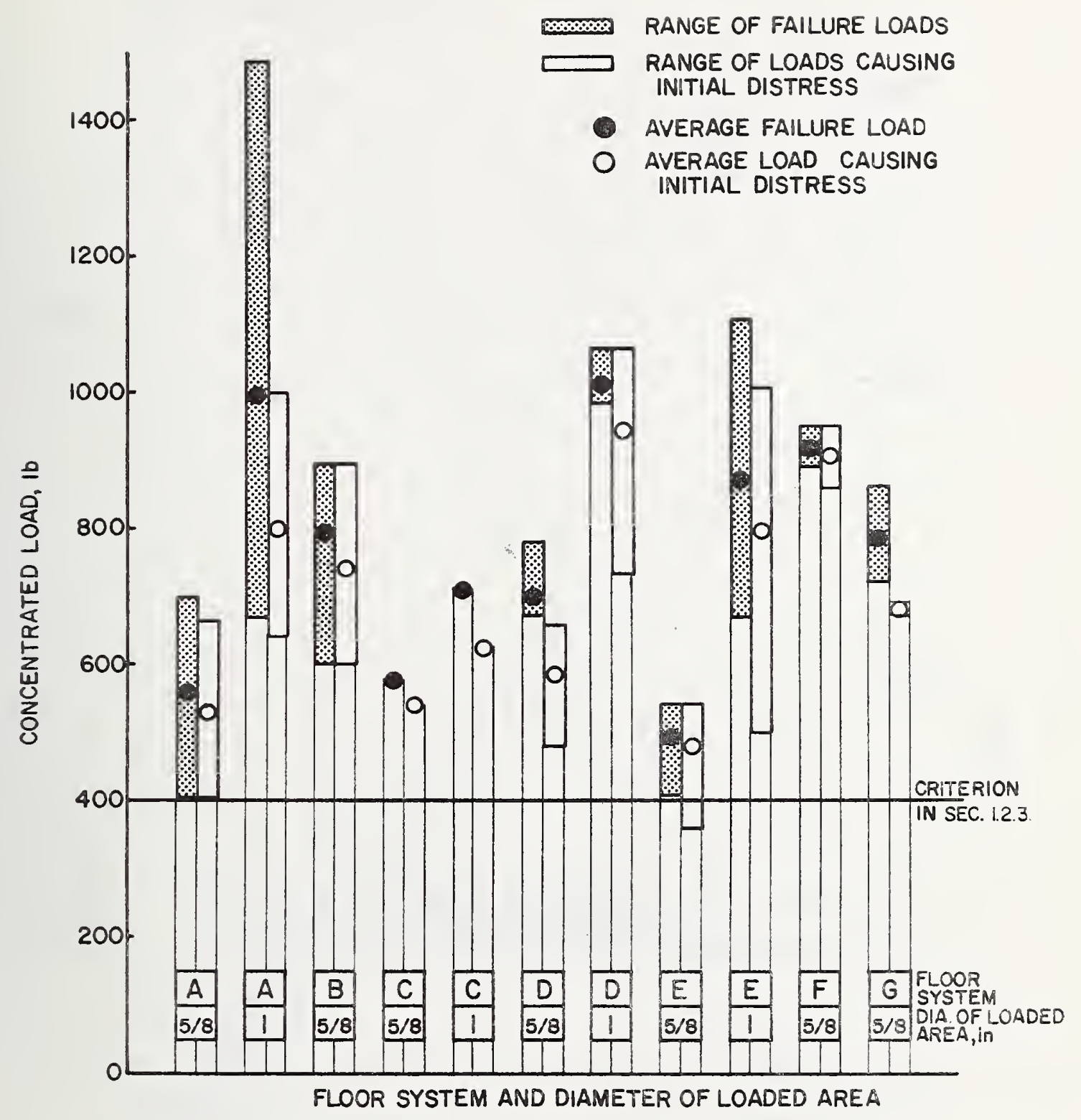

FIGURE 6.1 RANGE AND AVERAGES OF TEST RESULTS FOR TEST LOCATIONS I AND IU 


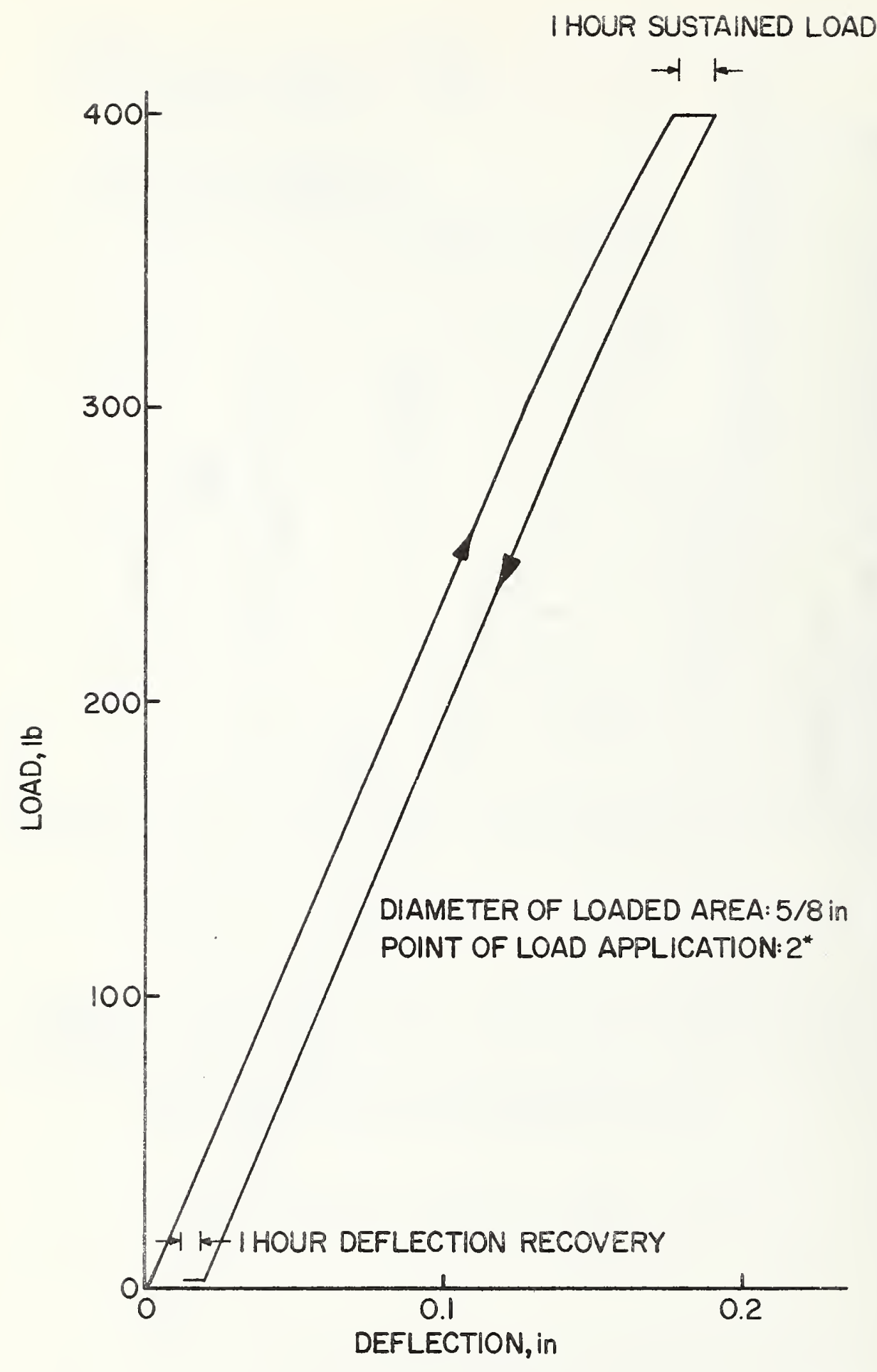

FIGURE 6.2 CGMPLIANCE OF FLOOR SYSTEM C WITH BREAKTHROUGH CRITERION

* See Figure 5.1 


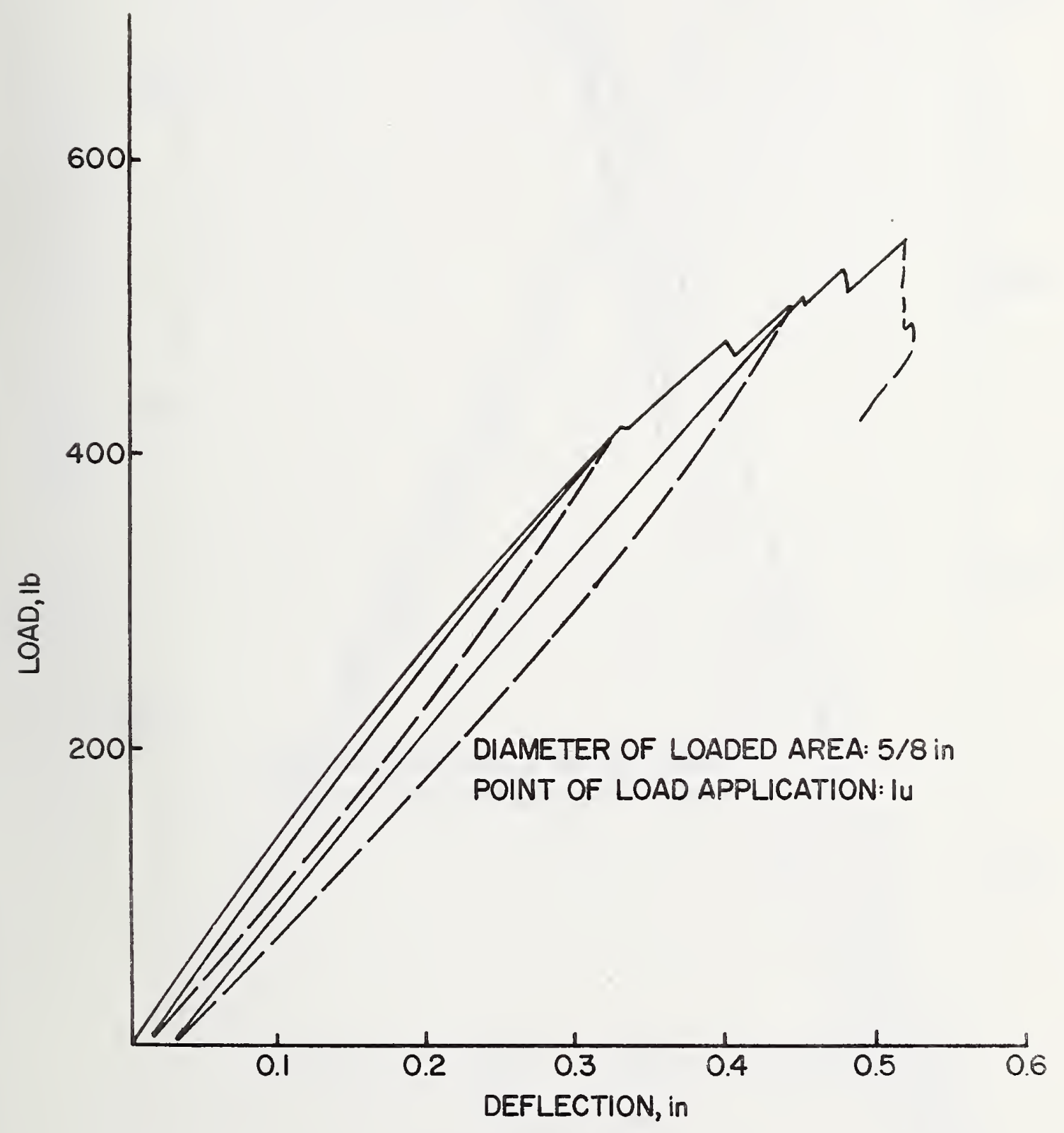

FIGURE 6.3 DEFLECTION RECOVERY CHARACTERISTICS OF FLOOR SYSTEN A 


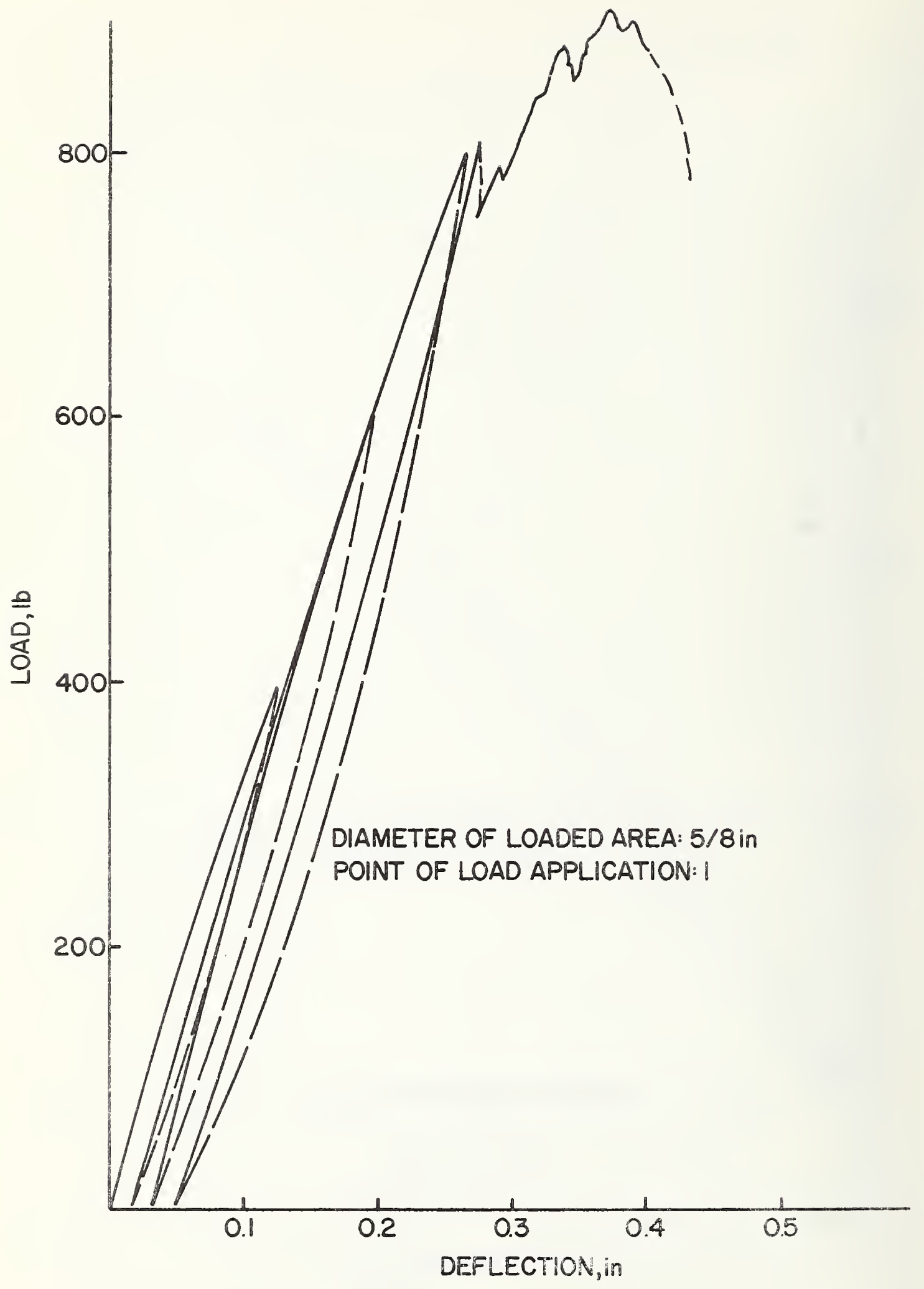

FIGURE 6.4 DEFLECTION RECOVERY CHARACTERISTICS OF FLOOR SYSTEM B 


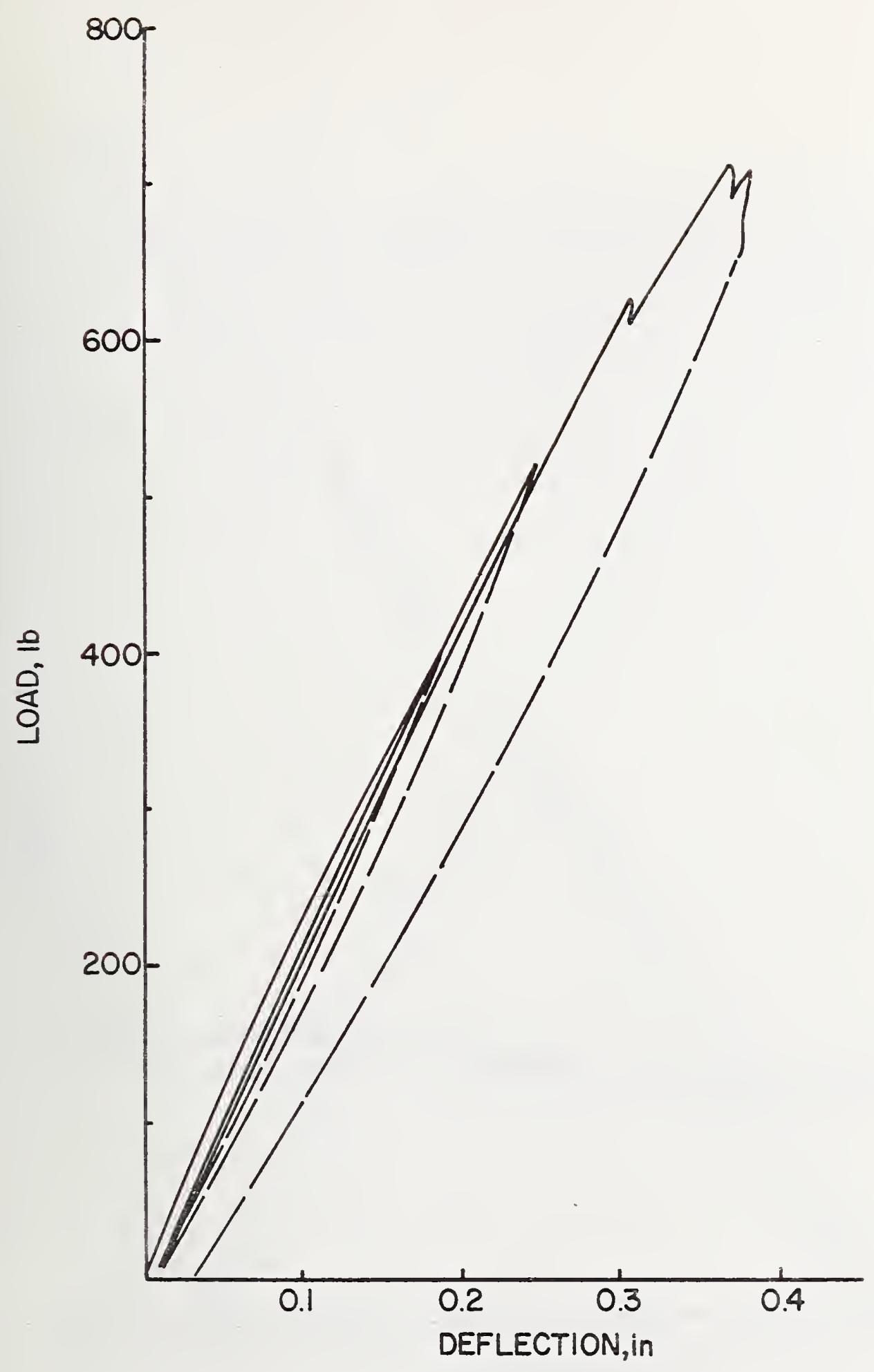

FIGURE 6.5 DEFLECTION RECOVERY CHARACTERISTICS OF FLOOR SYSTEM $C$ 


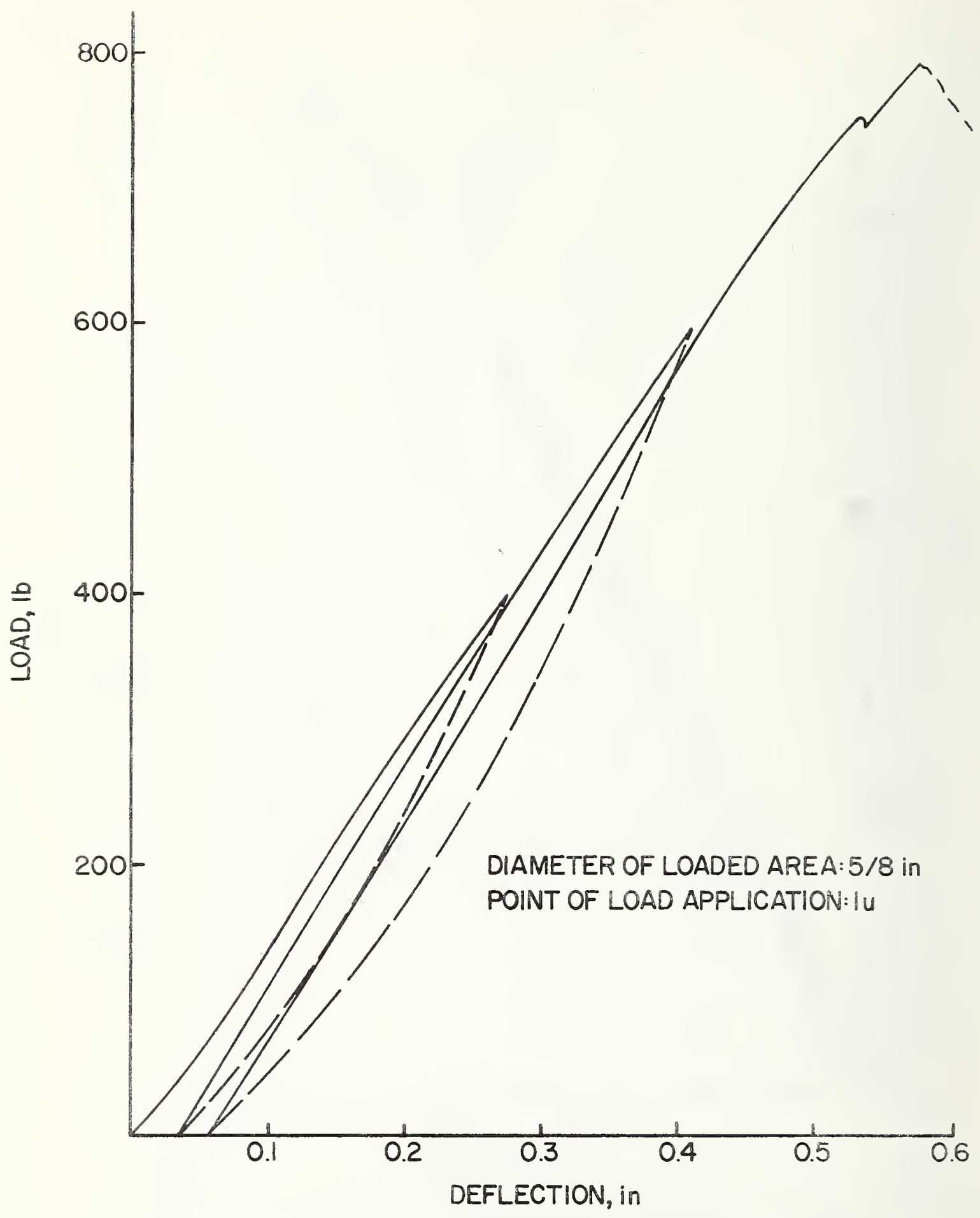

FIGURE 6.6 DEFLECTION RECOVERY CHARACTERISTICS OF FLOOR SYSTEM $F$ 


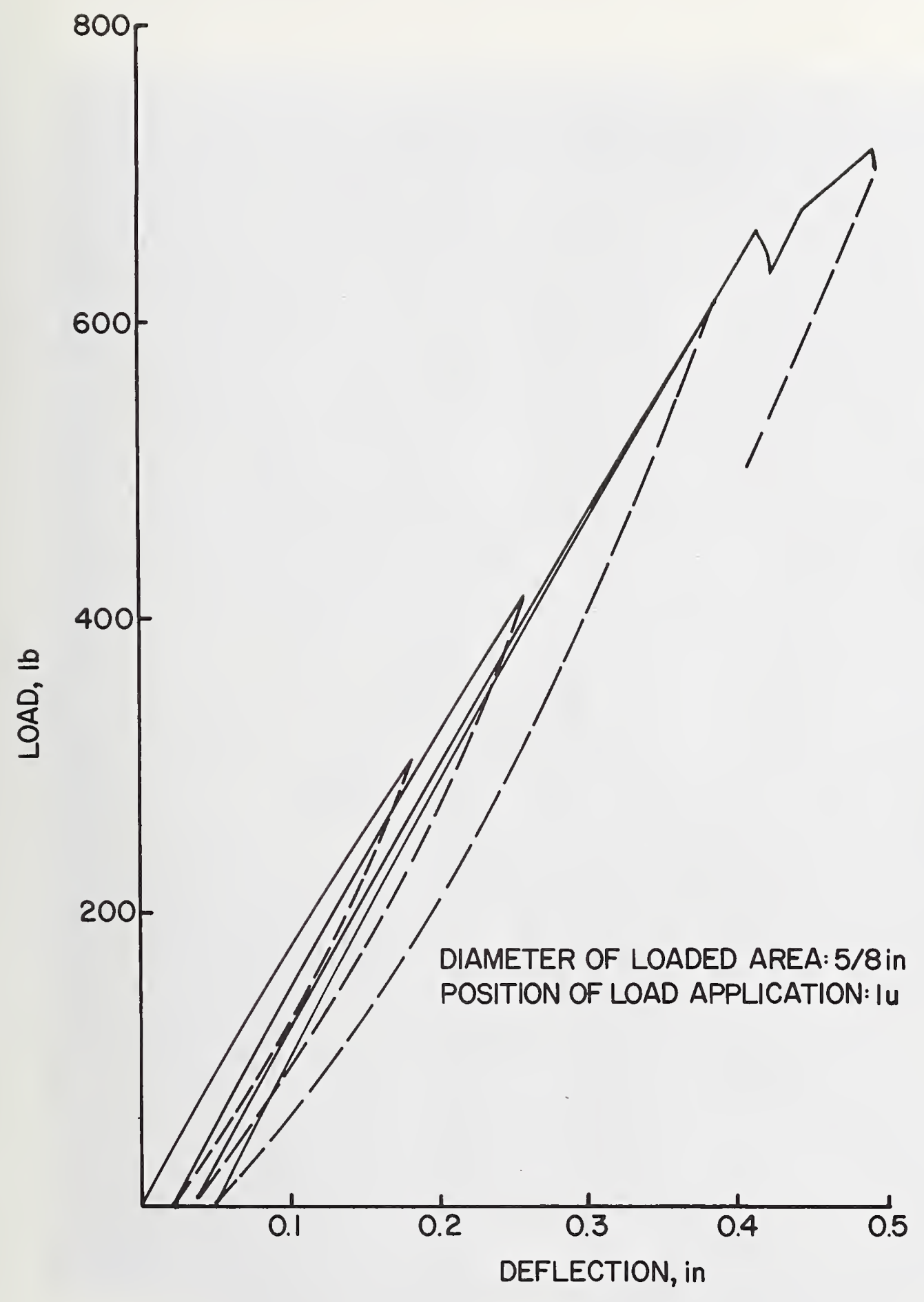

FIGURE 6.7 DEFLECTION RECOVERY CHARACTERISTICS OF FLOOR SYSTEM G 


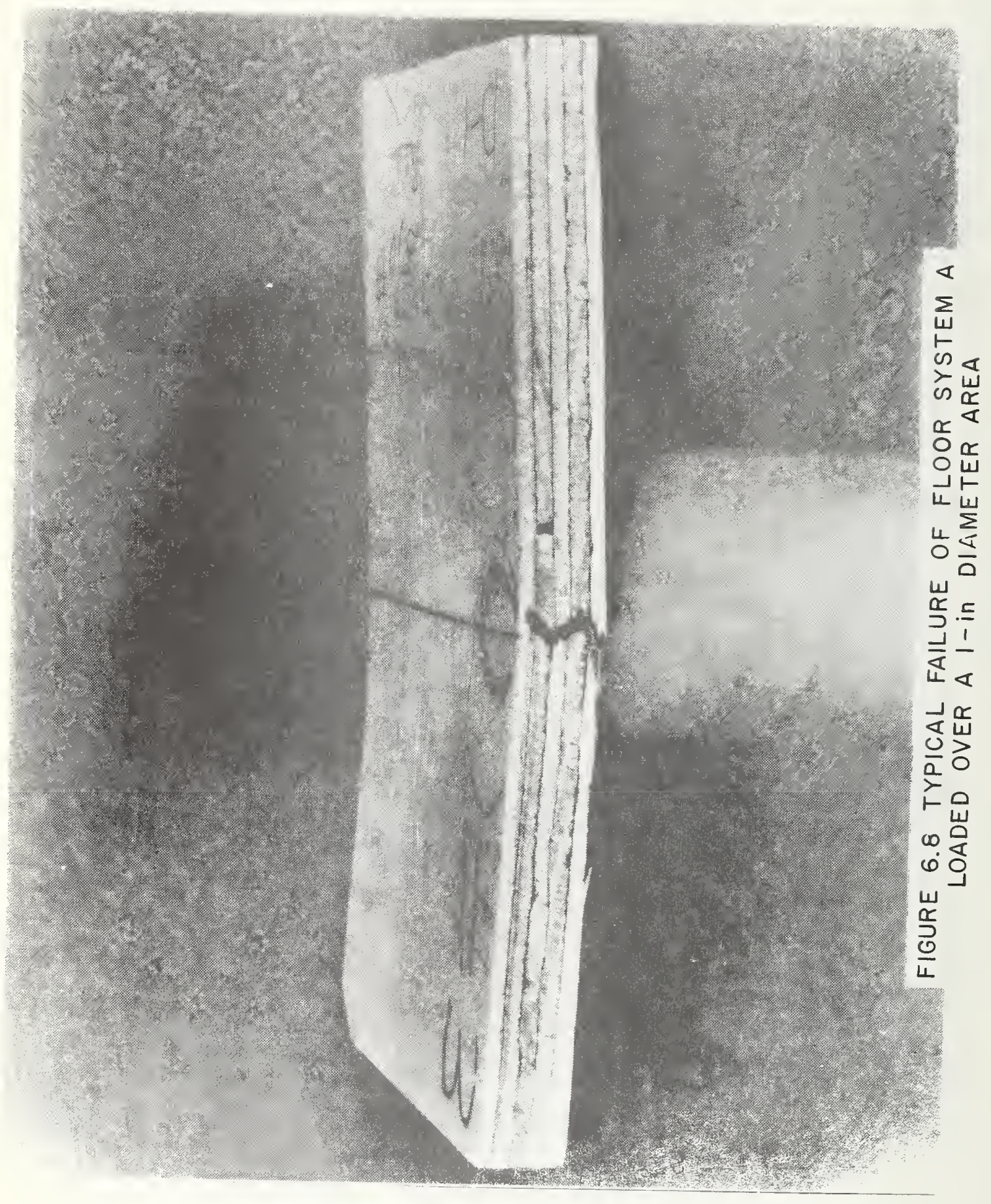




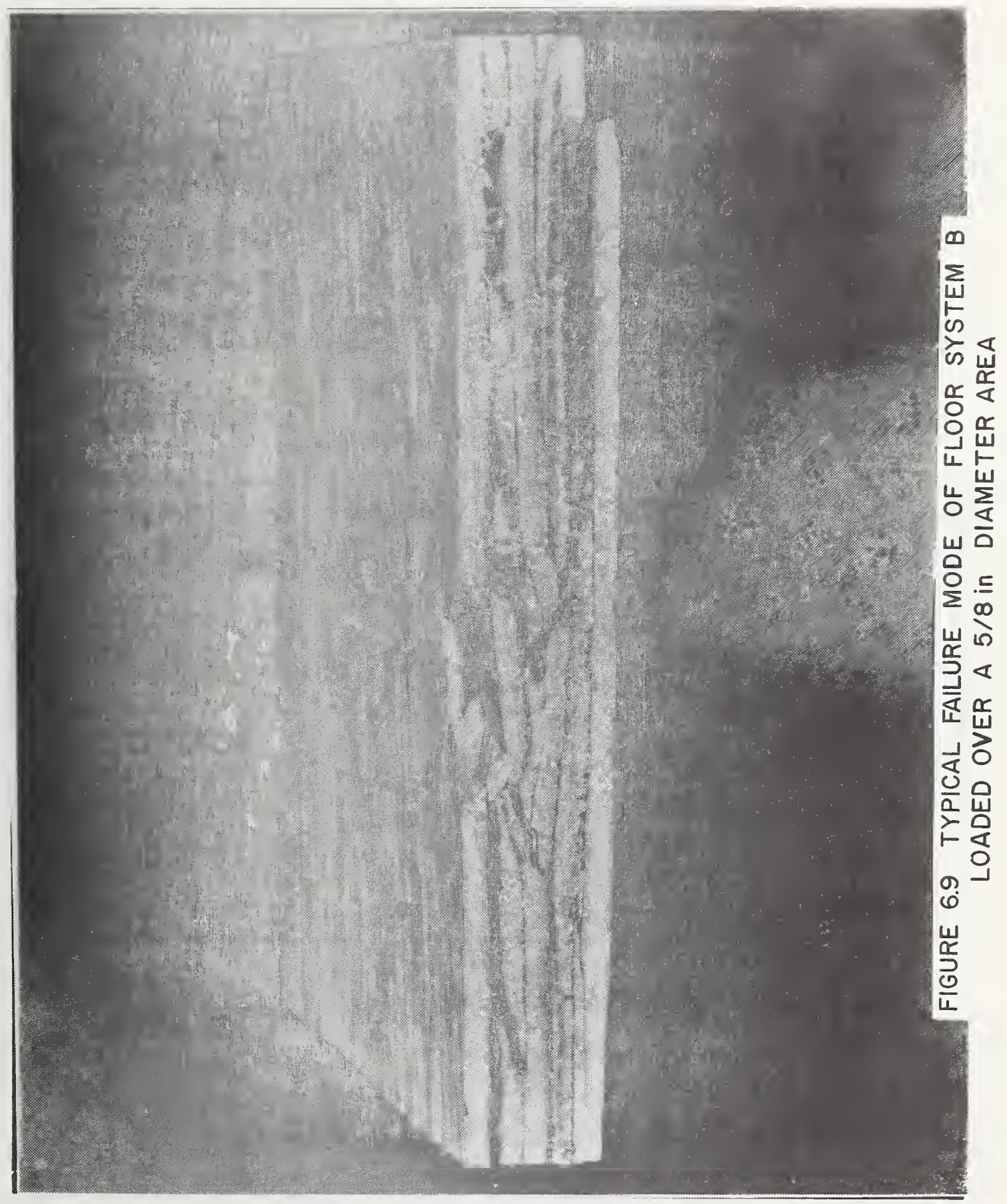




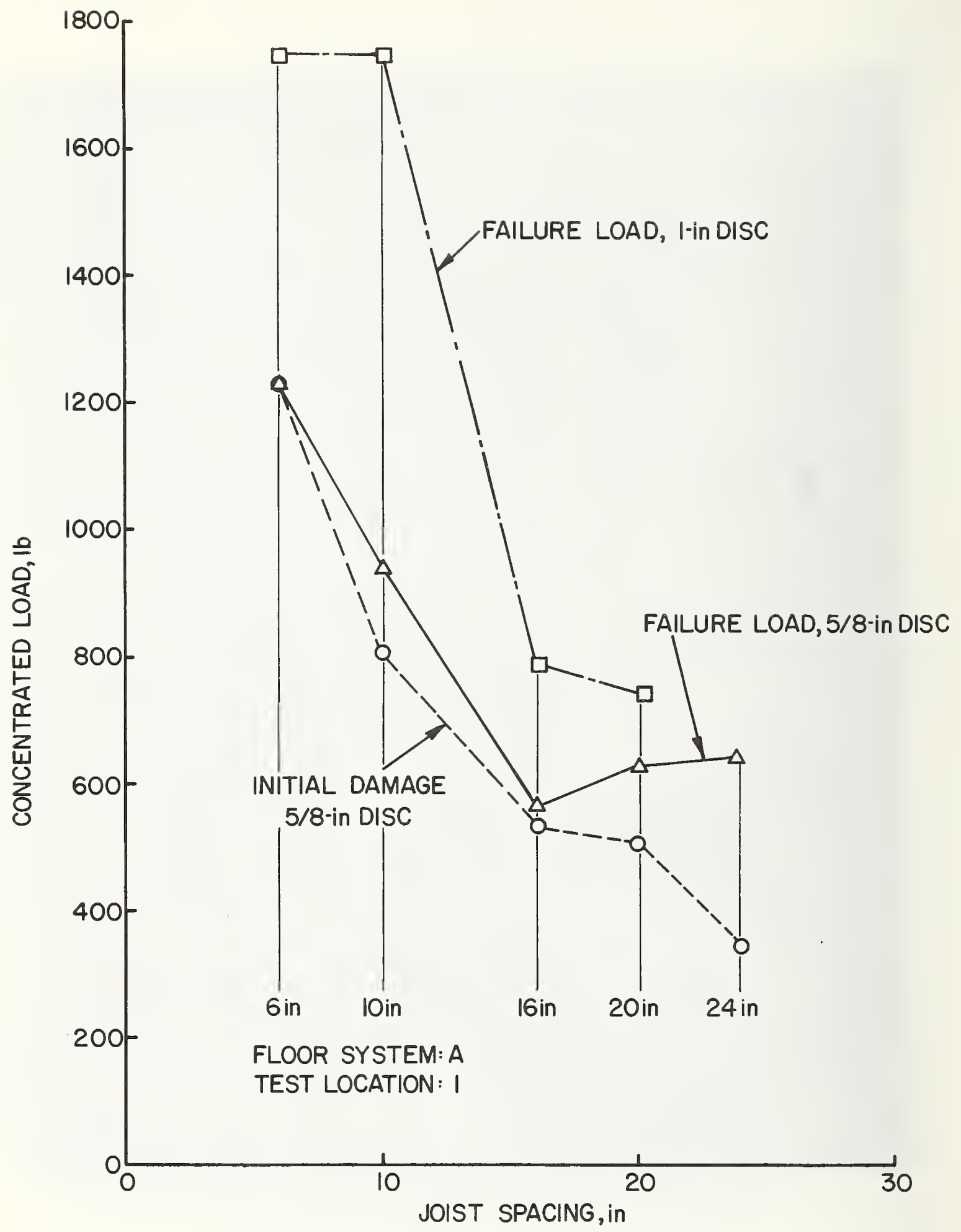

FIGURE 6.10 RELATIONSHIP BETWEEN JOIST SPACING AND STRENGTH 


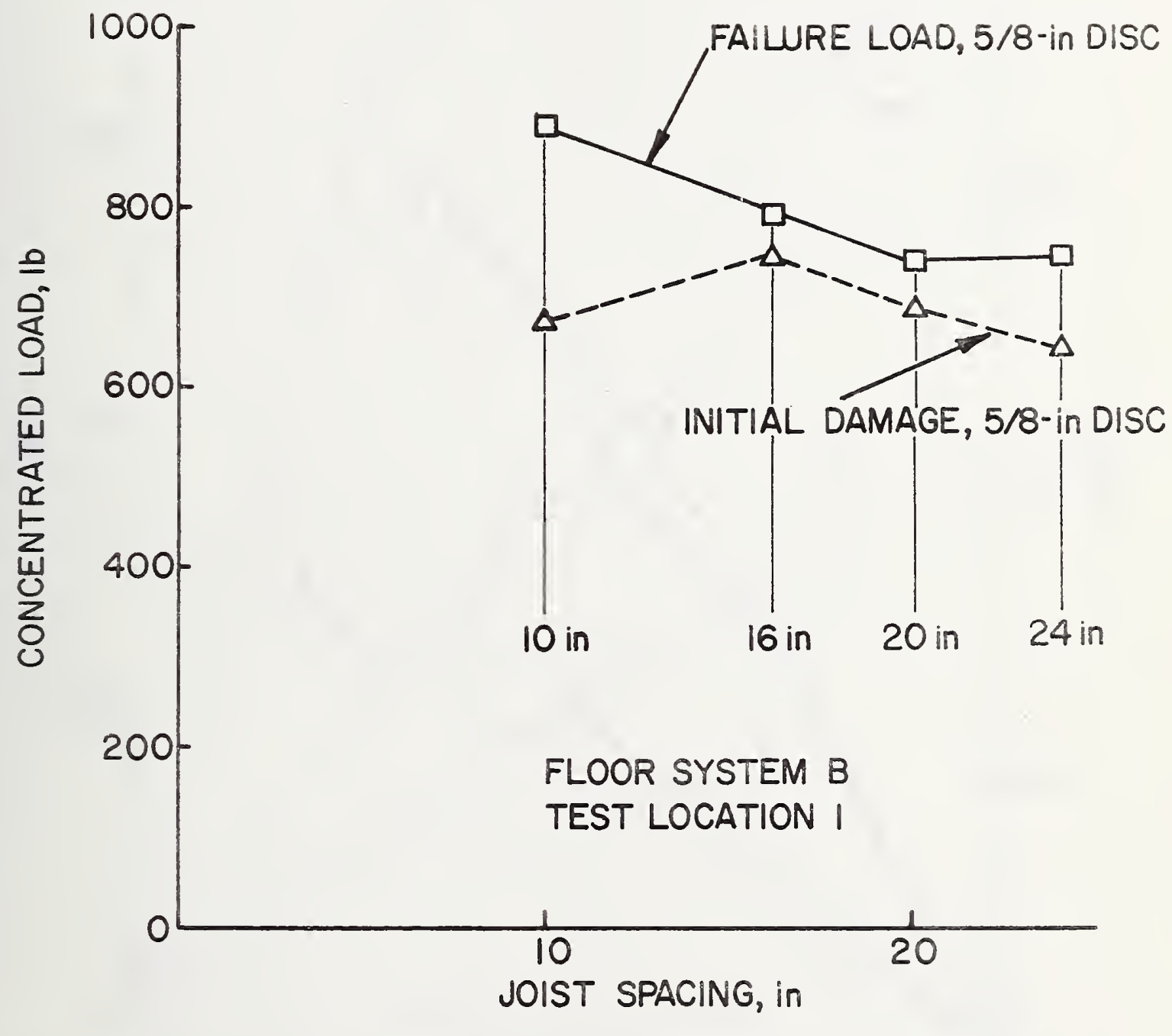

FIGURE 6.11 RELATIONSHIP BETWEEN JOIST SPACING AND STRENGTH 


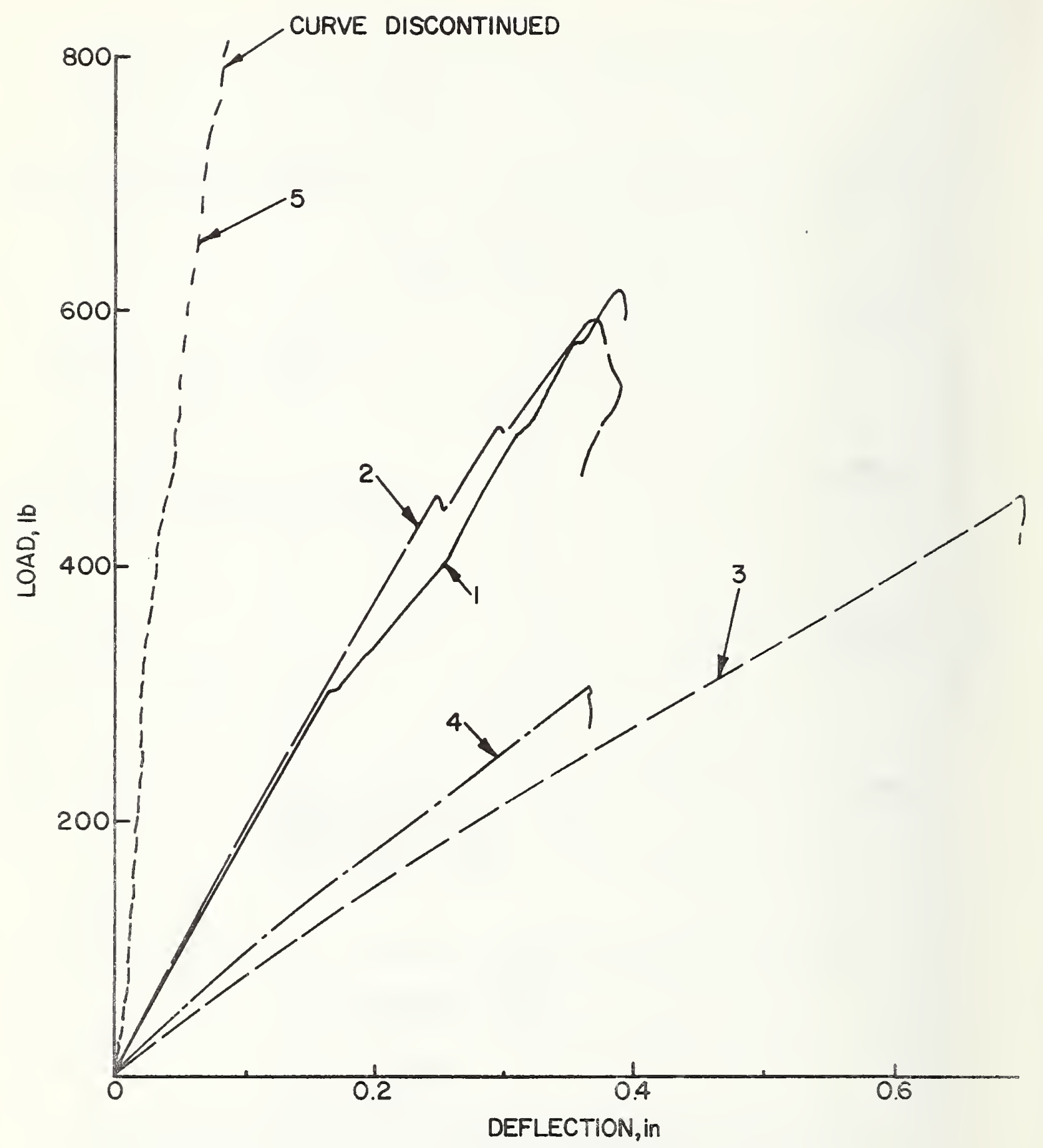

FIGURE 6.12 RELATIONSHIP BETWEEN THE LOAD-DEFLECTION

CHARACTERISTICS AND THE POSITION OF TIEE CONCENTRATED LOAD FOR FLONR SYSTENA A 


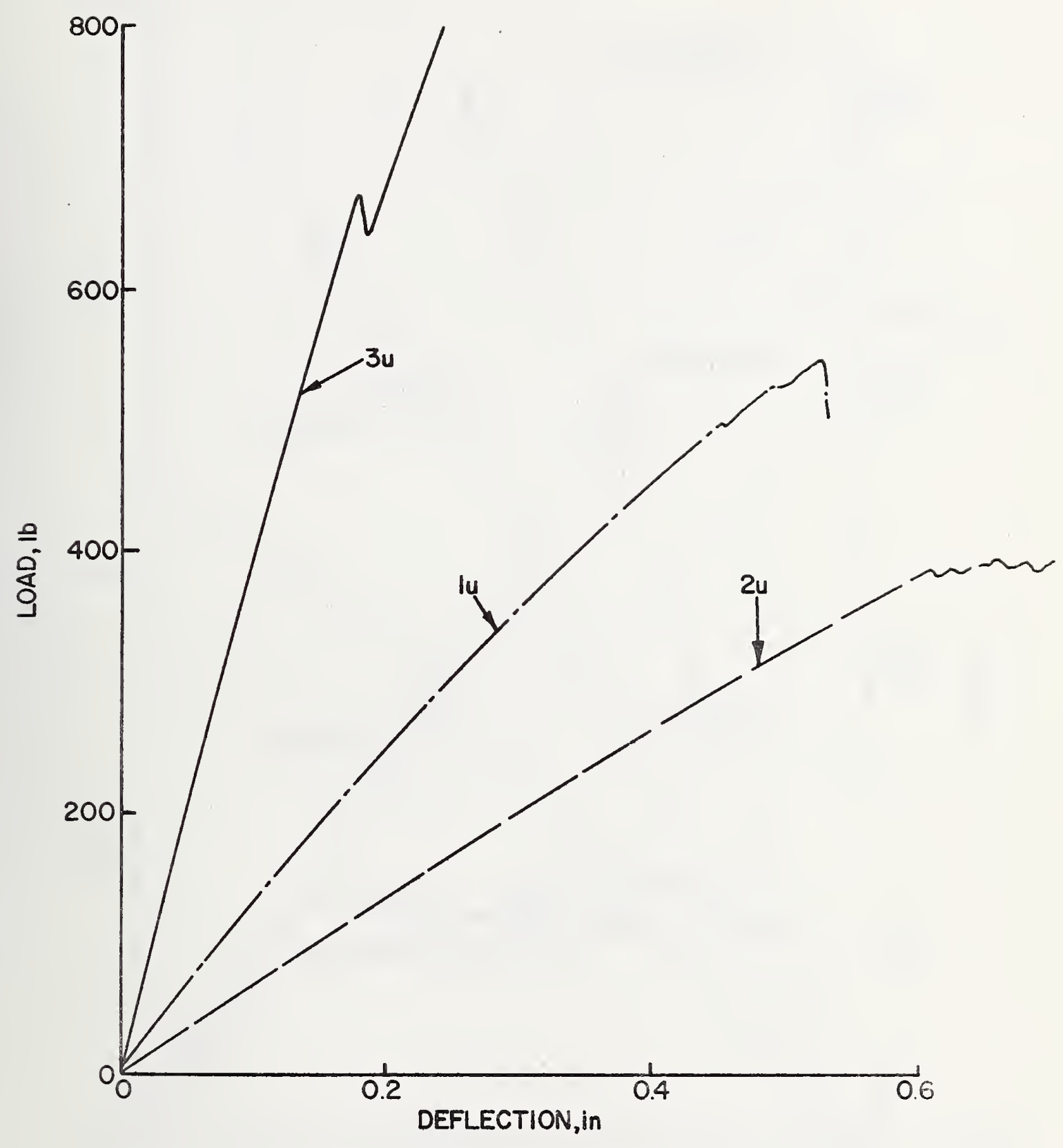

FIGURE 6.13 RELATIONSHIP BETWEEII LOAD-DEFLECTION CHARACTERISTICS AND THE POSITION OF THE CONCENTTATED LOAD FOR FLOOR SYSTEM E 


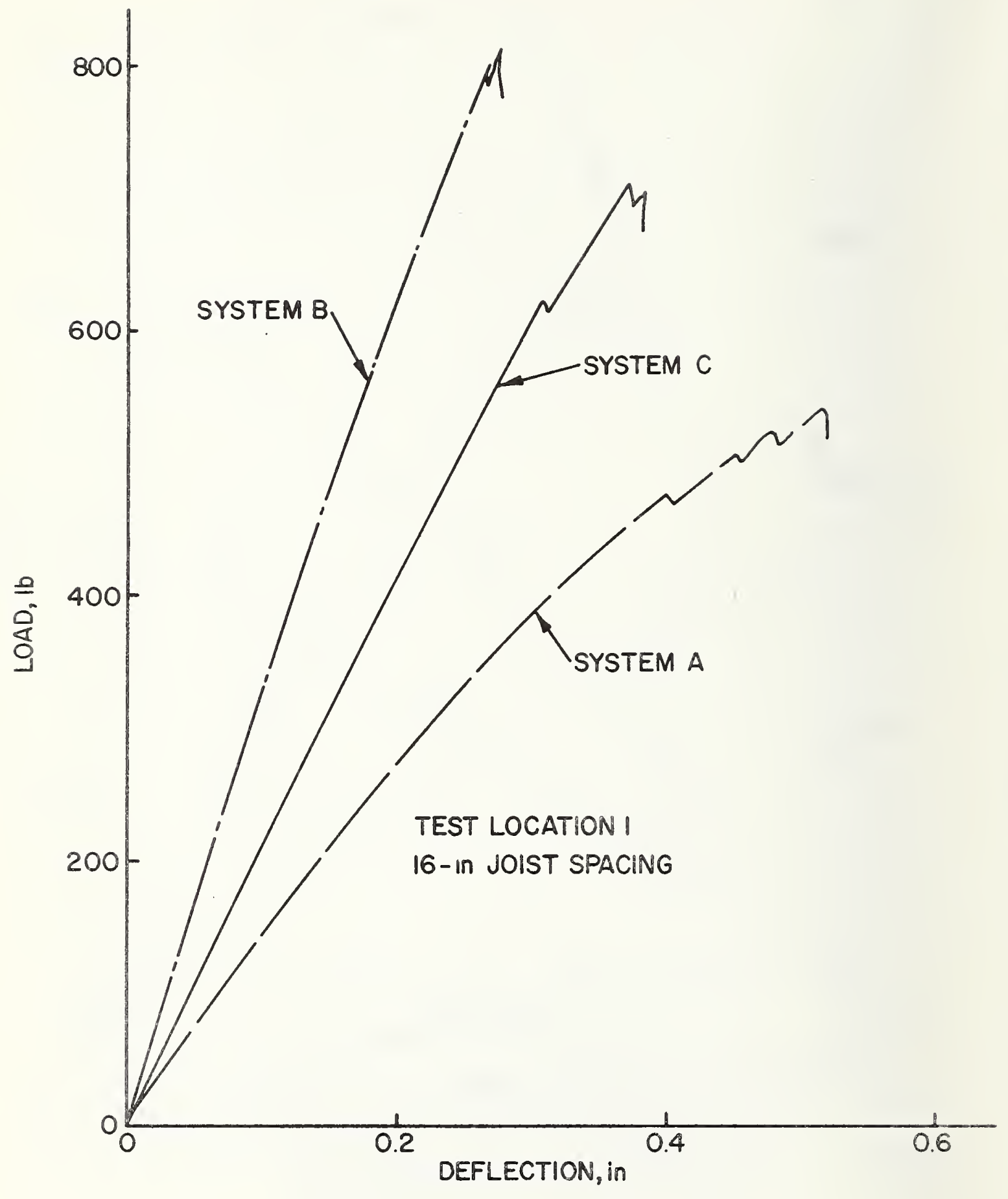

FIGURE 6.14 RELATIVE STIFFNESS OF FLOOR SYSTEMS WITHOUT UNDERLAYMENT 


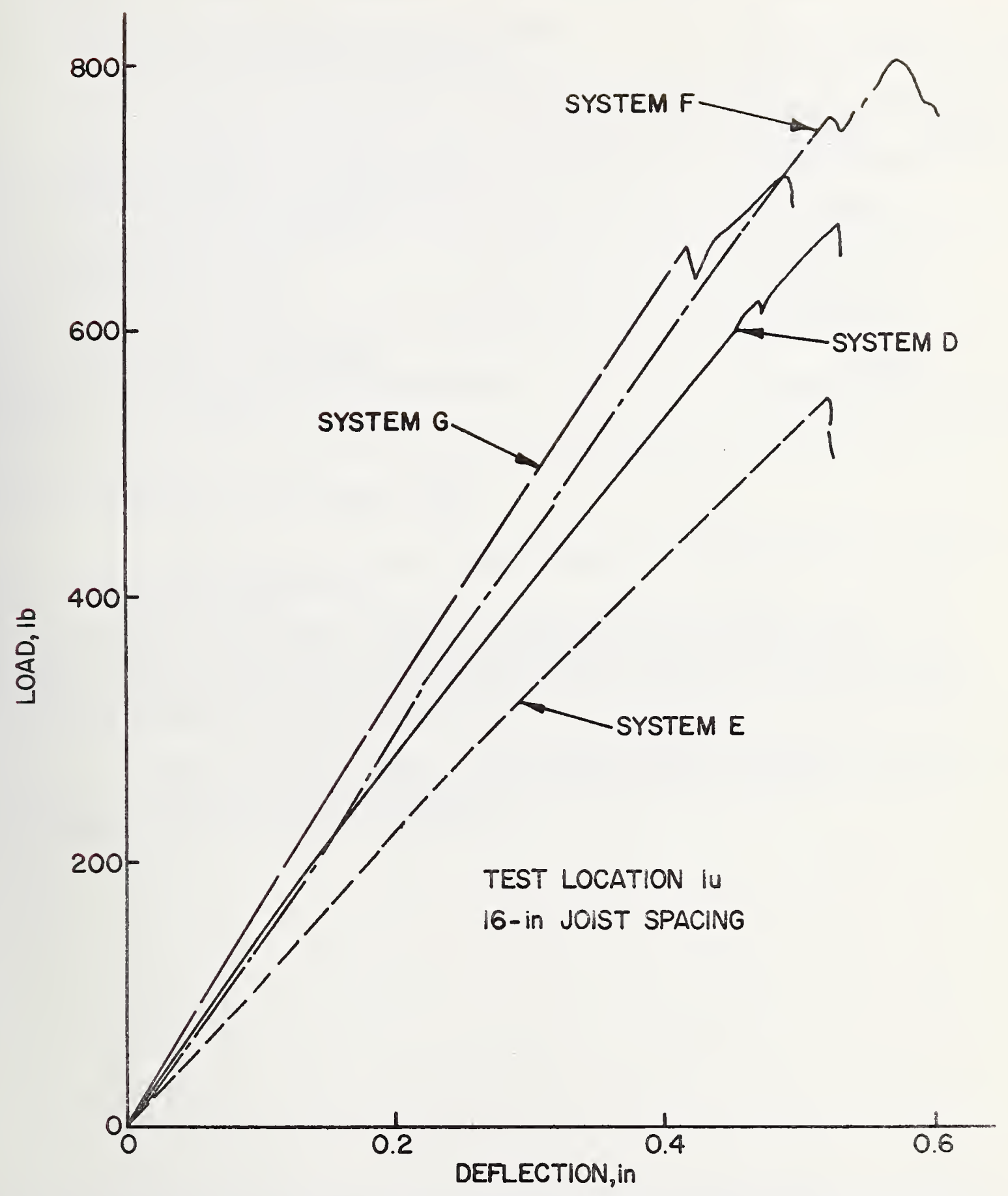

FIGURE 6.15 RELATIVE STIFFIESS OF FLOOR SYSTEMS WITH UNDERLAYMENT 
I ORM NBS-114A (1-11)

\begin{tabular}{|c|c|c|}
\hline \begin{tabular}{c|c|} 
U.S. DEPT. OF COMM. & 1. PUIBLICATION OR REPOK'T NO. \\
BIBLIOGRAPHIC DATA & NBSIR \\
SHEET & $73-116$ \\
\end{tabular} & $\begin{array}{l}\text { 2. Gov't Accession } \\
\text { No. }\end{array}$ & 3. Recipicent's Accession Nu \\
\hline \multirow{3}{*}{\multicolumn{2}{|c|}{$\begin{array}{l}\text { Study of the Local Resistance of Conventional } \\
\text { Plywood Subflooring to Concentrated Load }\end{array}$}} & 5. Publication 1)ate \\
\hline & & \\
\hline & & 6. Performing Organization Code \\
\hline 7. $A 1110 \mathrm{H}(S)$ & & $\begin{array}{l}\text { 8. Performing Organization } \\
\text { NBSIR } 73-116\end{array}$ \\
\hline \multirow{2}{*}{\multicolumn{2}{|c|}{$\begin{array}{l}\text { 9. PLERIORMING ORGANIZATION NAME AND ADDRESS } \\
\text { NATIONAL BUREAU OF STANDARDS } \\
\text { DEPARTMENT OF COMMERCE } \\
\text { WASIIINGTON, D.C. } 20234\end{array}$}} & $\begin{array}{l}\text { 10. Project Task Work Init Nu. } \\
4600460\end{array}$ \\
\hline & & $\begin{array}{l}\text { 11. Contract/Grunt No. } \\
\text { IAA-H-16-70 }\end{array}$ \\
\hline \multirow{2}{*}{\multicolumn{2}{|c|}{$\begin{array}{l}\text { 12. Sponsoring Organization Name and Address } \\
\text { Office of Research \& Technology } \\
\text { Department of Housing \& Urban Development } \\
\text { Washington, D. C. } 20410\end{array}$}} & $\begin{array}{l}\text { 13. Type of Report \& Period } \\
\text { Covered } \\
\text { Final }\end{array}$ \\
\hline & & 14. Sponsoring Agency Code \\
\hline
\end{tabular}

\section{SUPPLEMENTARY NOTES}

This is a revision of NBS Report 10315

16. ABSTRACT (A 200-word or less factual summary of most significant information. If document includes a significant bibliography or literature survey, mention it here.)

Five conventional plywood floor systems, constructed in accordance with the requirements of the FHA "Minimum Property Standards" were tested under concentrated loads in order to compare their performance with that stipulated by performance criteria developed on the basis of anticipated occupancy loads.

In 24 our of 26 tests the performance of the floor systems exceeded that stipulated by the criteria. Data on failure loads, load-deflection characteristics and failure modes are presented and discussed.

17. KEY WORISS (Alphabetical order, separated by semicolons) Concentrated-Ioad capacity; evaluation criteria; floors; hardboard; load capacity; Operation BREAKTHROUGH; perfomance criteria; plywood subflooring; subflooring; underlayment; wood-frame construction. 18. AVAILABILITY STATEMENT

X ] UN1.IM1TE1). 
